\title{
Reprimarização no Território Brasileiro
}

Reprimarizacion in the Brazilian Territory

Reprimarización en el Território Brasileño

La re-primarisation dans le territoire brésilien

\section{Lisandra Pereira Lamoso}

\section{(2) OpenEdition \\ Journals}

\section{Edição electrónica}

URL: https://journals.openedition.org/espacoeconomia/15957

DOI: 10.4000/espacoeconomia.15957

ISSN: 2317-7837

\section{Editora}

Núcleo de Pesquisa Espaço \& Economia

\section{Refêrencia eletrónica}

Lisandra Pereira Lamoso, «Reprimarização no Território Brasileiro», Espaço e Economia [Online], 19 | 2020, posto online no dia 02 setembro 2020, consultado o 21 setembro 2021. URL: http:// journals.openedition.org/espacoeconomia/15957 ; DOI: https://doi.org/10.4000/espacoeconomia. 15957

\section{Este documento foi criado de forma automática no dia 21 setembro 2021.}

\section{cc)}

Espaço e Economia - Revista brasileira de geografia econômica est mise à disposition selon les termes de la licence Creative Commons Attribution - Pas d'Utilisation Commerciale - Partage dans les Mêmes Conditions 4.0 International. 


\title{
Reprimarização no Território Brasileiro
}

\author{
Reprimarizacion in the Brazilian Territory \\ Reprimarización en el Território Brasileño \\ La re-primarisation dans le territoire brésilien
}

Lisandra Pereira Lamoso

\section{Introdução ${ }^{1}$}

1 O Brasil possui um dos parques industriais mais complexos da América Latina, o que lhe confere o oitavo maior Produto Interno Bruto (PIB) mundial (FUNDO MONETÁRIO INTERNACIONAL, 2017) que, embora expressivo, participou com apenas 1,6\% no total das exportações mundiais em 2016 (WORD TRADE ORGANIZATION, 2017). Essa industrialização, implantada na forma de substituição de importações, teve um início sistemático induzido pelo planejamento estatal, na década de trinta. Caracteriza-se, espacialmente, por uma maior concentração nas capitais dos estados das regiões nordeste, sudeste e sul, manchas que se interiorizam no centro-oeste devido à forte vinculação com a demanda externa por grãos e, na região norte, com presença da política de proteção dada pela Zona Franca, em Manaus.

2 Este parque industrial foi o responsável pela inserção da economia brasileira no mercado mundial de manufaturados, com mais vigor a partir da década de setenta, quando as exportações de produtos primários foram superadas pelas exportações de produtos industrializados, consolidando a agregação de valor, acompanhado e suportado por um intenso processo de urbanização.

3 A complexidade do parque industrial provoca, no território brasileiro, uma maior densidade técnica e esta densidade é utilizada pelo parque industrial, em uma via de mão-dupla. A indústria, em seu funcionamento, impõe demandas para um conjunto de objetos que agruparemos, para efeitos de diálogo neste texto, sob o termo "aparato de suporte industrial". Este aparato de suporte industrial é formado: pelo setor energético, com a construção de sistemas de geração e distribuição de energia (que pode ser 
elétrica, eólica, nuclear, solar, fóssil, biomassa, ...); pela disponibilidade de matériaprima (arranjos produtivos no campo e na cidade); pela circulação de matéria-prima e produto final (através de rodovias, ferrovias, hidrovias, aerovias, dutovias, ...); por redes de transmissão de dados (redes de telecomunicações, infovias); pela disponibilidade de mão-de-obra (local, regional, pendular); por uma rede de serviços (financeiros, comerciais, terceirizados autônomos, marketing, consultorias, planejamento...); pela rede de serviços industriais de utilidade pública (como saneamento, eletrificação, abastecimento de água) além de uma extensa ordem de demandas imateriais (ordenamento de uso dos espaços públicos e privados, tributação, regulação, arcabouço normativo, jurídico,...). Este conjunto, aqui resumido, está diretamente relacionado à atividade industrial e reflete tanto seu dinamismo e expansão quanto seu processo de retração. Pensar neste aparato de suporte industrial é considerar o espaço, como propôs Santos (1996), como um sistema de objetos e ações.

Esse aparato de suporte industrial foi/é planejado e está construído voltado para a demanda externa, numa ligação histórica, abordada por Rangel (2005), da economia brasileira ao centro dinâmico do capitalismo industrial. Compartilhamos com Arroyo (2014) que "los flujos internacionales de mercaderías expresados em las exportaciones e importaciones muestran las relaciones que distintas fracciones del territorio nacional tienen cono el mundo a través de la actividad mercantil" (ARROYO, 2014, p.169)

Os fatores externos que influenciam na organização das estruturas produtivas nacionais estão relacionados aos preços de determinadas mercadorias, conforme a conjuntura, mas sempre relacionadas à hegemonia do capital financeiro. Lucros, dividendos, interesses de curto prazo e uma extrema fragmentação produtiva expressa pelas cadeias globais de valor são elementos que se associam aos pactos de poder interno que definem as orientações da política de desenvolvimento econômico (ou a falta dela).

6 Em se tratando de desenvolvimento econômico, nosso entendimento é filiado aos autores Kaldor (1967), Schumpeter (1982), Rangel (2005) que entendem ser a indústria o motor do desenvolvimento econômico pelos efeitos encadeadores que define para a agricultura e para os serviços, efeitos multiplicadores para toda economia, e por ser diretamente responsável pelo desenvolvimento tecnológico, pelo avanço do progresso técnico e seu espraiamento na melhoria das condições de vida da sociedade. Por isso, é conferido à indústria um protagonismo no processo de desenvolvimento econômico e, no caso brasileiro, este está diretamente relacionado às condições nas quais ocorre sua participação no comércio internacional. O Brasil se constitui enquanto nação na dependência de suas relações com o mercado externo e responde aos seus estímulos de expansão ou retração, reorganizando as estruturas produtivas no território.

7 Quando consideramos a distribuição do aparato de suporte industrial, observando-o segundo as unidades da federação temos que o centro sul e as capitais litorâneas tem sido, ao longo de décadas, aparelhadas para garantir a reprodução da acumulação com a maior eficiência possível, dado o progresso técnico disponível em cada momento histórico, bem como a disponibilidade de capital. A princípio, isso nos levaria a considerar que os estados que mais exportam manufaturados são aqueles com maior grau de industrialização e os estados nos quais predominam a produção agropecuária com maior participação no PIB seriam os estados exportadores de produtos básicos. Os estados mais dotados de serviços sofisticados, maior densidade demográfica, maior 
disponibilidade de redes de circulação e serviços financeiros seriam os maiores exportadores de produtos industrializados e semimanufaturados.

8 As condições recentes apresentam uma composição que merece atenção porque na escala nacional já chegou ao fenômeno da reprimarização (ver Figura 4). A evolução da participação relativa das exportações de básicos superou a participação de manufaturados e semimanufaturados no ano de 2010. Essa reprimarização foi acompanhada de desindustrialização. Neste texto, nos dedicaremos ao primeiro fenômeno, com o objetivo de compreender em quais estados a reprimarização se manifesta.

9 Para isso, tomamos os dados das exportações disponíveis no Ministério do Desenvolvimento, Indústria e Comércio, classificados por fator agregado (manufaturados, semimanufaturados e básicos) entre os anos de 2000 e 2016, em milhões de dólares FOB. Com isso construímos gráficos de evolução das exportações por fator agregado para todos os estados. Também apresentamos um mapa com o fator agregado predominante por estado para o ano de 2018. A argumentação está apresentada em três tópicos além desta Introdução. Iniciamos com alguns elementos característicos do processo de Globalização para, num segundo momento, pontuar a reprimarização no território brasileiro, por estados da federação. Nas considerações finais, chamamos a atenção para a reprimarização de dois importantes estados industriais, Paraná e Rio Grande do Sul.

\section{Alguns elementos da Globalização e suas implicações no território nacional}

10 A participação das corporações nas decisões políticas e econômicas dos Estados nações é um fato destacado na Globalização, a ponto de estudos de Santos (2000), cunharem a expressão "uso corporativo do território". A extensão da ação das corporações e o aumento do grau de financeirização das mesmas é um vetor de influência não só no território brasileiro como nos espaços da economia mundial. Em que pese a extensa literatura sobre a Globalização, que a aborda sob diversas faces (como exemplo, Globalização econômica, Globalização cultural), nosso recorte se dá na leitura do papel do comércio internacional, que é a forma como o Brasil realiza sua inserção na economia internacional e, deste externo, recebe vetores que reorganizam o uso de seu território.

11 Os debates sobre a importância do comércio internacional e como considerá-lo estão em constante atualização. Neuss (2018) chamou a atenção para o fato de que os valores absolutos de comércio ou a participação relativa dos países no mercado internacional é um indicativo frágil. $\mathrm{O}$ autor sugere a utilização de dados sobre o valor agregado das mercadorias, além do papel dos investimentos estrangeiros diretos, suas entradas e saídas e a terceirização offshore. Por exemplo, quando consideramos os valores brutos das exportações de minério, por mais significativas que sejam, pouco compreendemos sobre as estruturas produtivas nacionais. $\mathrm{O}$ fator agregado difere minério de ferro de aço, e considera que uma exportação de aço é melhor que de minério e uma exportação de aviões é melhor que exportar aço. Por isso construímos nossos dados considerando o fator agregado para discutir a reprimarização.

12 Sobre a produção fora do território, vejamos caso do Iphone. Para os Estados Unidos, concentrar a produção física de Iphone não é o principal, o importante é manter a sede 
da Apple em seu território, o poder decisório e a capacidade de inovação, de pautar o progresso técnico. $O$ outsourcing deve ser captado como medida do peso que o país tem na economia internacional. Neste quesito há baixa internacionalização das empresas brasileiras. Ao tratar de outsourcing, nos deparamos com uma segunda característica que é a inserção em Cadeias Globais de Valor (CGV). Desde início dos anos setenta, as exportações de bens finais são formadas, cada vez mais por importações de bens intermediários complexos, customizados, produtos específicos, quase sempre sofisticados (HUMPHREY; SCHIMITZ, 2002). Quanto mais os bens intermediários são comercializados entre os países mais peças e componentes são importados para comporem essa produção.

No caso brasileiro, trabalho de Ferreira e Scheneider (2015) conclui que o Brasil possui forte ligação com outros países que utilizam insumos em suas exportaçães, mas que os produtos principais da participação brasileira são resultados diretos da exploração de recursos naturais, como mineração, agricultura e metais básicos (Ver Figura 1).

Em três gráficos (Ver Figuras 1, 2 e 3), podemos observar que a evolução de duas commodities minerais destacados segue uma tendência de alta ao longo do período analisado, sendo o caso de óleos brutos de petróleo, minérios de ferro e seus concentrados. Quanto aos principais produtos ligados ao agronegócio, carne bovina, carne de frango e celulose, também houve uma tendência de aumento. Quando apresentamos industrializados, a tendência acumulada expressa queda para o mesmo período (Ver Figura 3), é o caso de automóveis de passageiros, motores para veículos automóveis e suas partes, e aviões, justamente o último, produto de maior intensidade tecnológica.

Figura 1 - Evolução das exportações de óleos brutos de petróleo e minérios de ferro e seus concentrados (2007-2019).

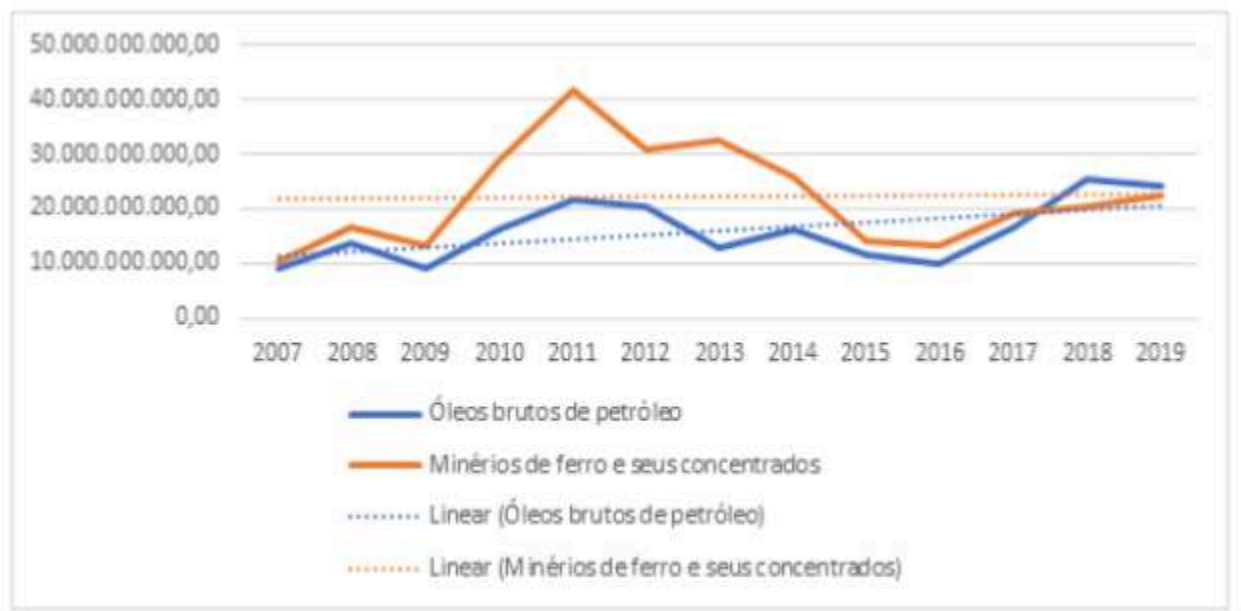

Fonte: MDIC, 2017. Org.: da Autora, 2019 
Figura 2 - Evolução das exportações de carne de bovino, carne de frango e celulose (2007-2019).

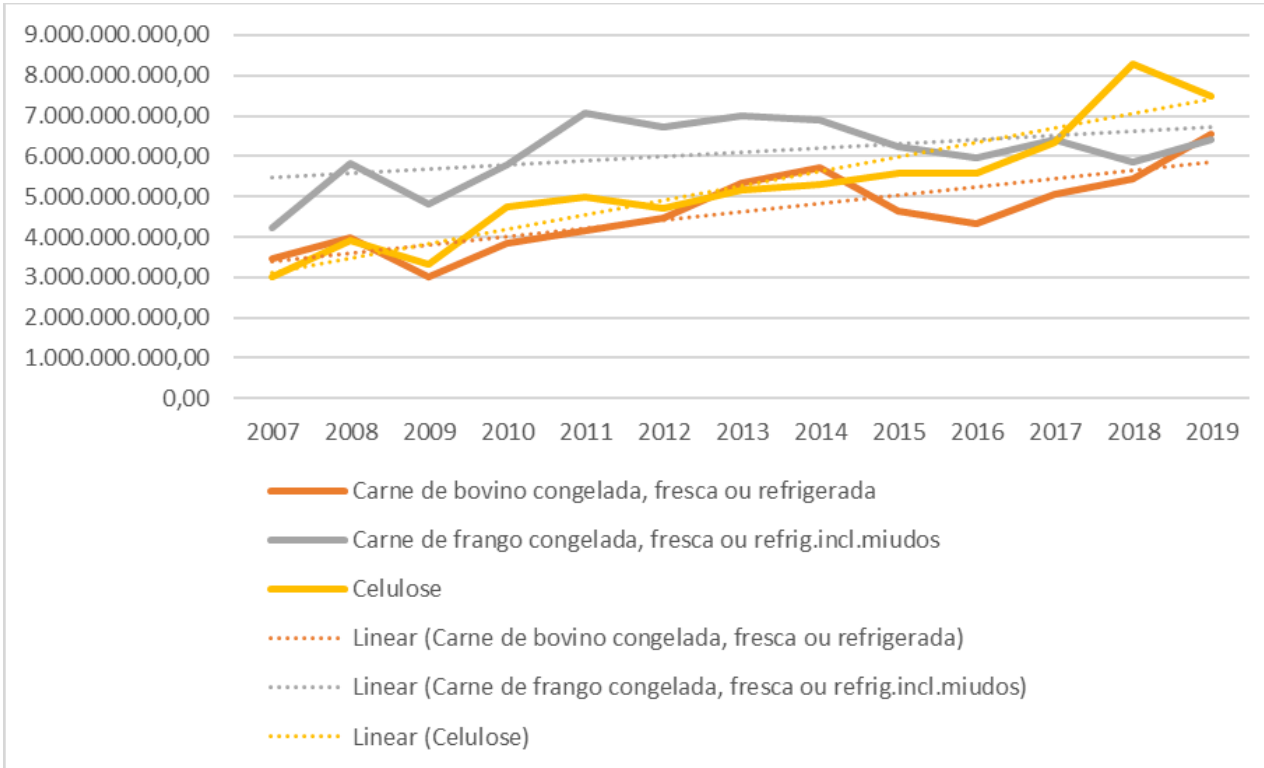

Fonte: MDIC, 2017. Org.: da Autora, 2019

Figura 3 - Evolução das exportações de automóveis de passageiros e motores para veículos e aviões. (2007-2019).

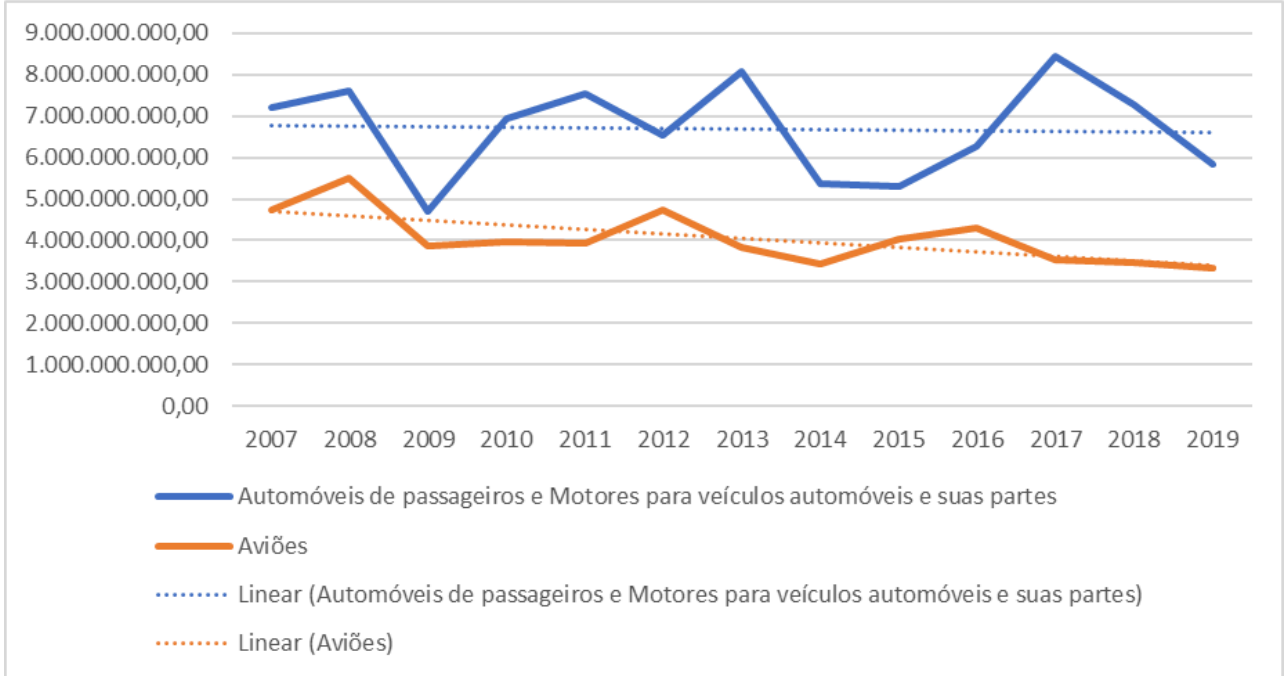

Fonte: MDIC, 2017. Org.: da Autora, 2019

O desenvolvimento econômico demanda qualificar essa inserção, ou seja, não se trata meramente de substituir a presença de recursos naturais por mercadorias mais sofisticadas mas algo mais complexo que é, manter e aproveitar o nível de produtividade e os ganhos já historicamente obtidos com essas exportações, conseguir transferir recursos para verticalização de cadeias produtivas e torná-las competitivas. Não se trata de alternativas, ou commodities ou industrializados, mas se aproveitar ambos, commodities e industrializados. Para Baldwin (2011), grandes países em desenvolvimento, como a China e a Índia, podem usar seus enormes mercados internos como estratégia e forçar empresas de tecnologia avançadas a transferir mais tecnologia. Poderíamos aplicar esse racícionio, com as devidas adaptações ao caso brasileiro. 

(2017). Diz respeito às condições atuais do acirramento da concorrência global e à reorganização das grandes empresas transnacionais. O Brasil conta com empresas que ocupam posições de destaque nos seus setores, como Vale, Petrobrás, Embraer, empresas de frigorificação de carne bovina e indústrias de celulose, para ficar em um pequeno rol de exemplos, já que o capital privado nacional tem sido cada vez mais ameaçado de redução. Excluída a Embraer, a maior atuação depende de recursos naturais intensivos.

17 Temos, nesse contexto, mais um elemento do processo de globalização, a impor desafios ao desenvolvimento econômico brasileiro: como enfrentar competição em custo acirrada, liderada pela produção chinesa, mas que envolve outros produtores asiáticos, que combinam custos de mão de obra, escala, câmbio, capacidade de planejamento estatal bastante potentes? (HIRAKUTA E SARTI, 2017). A conjuntura e a política nacional têm orientado para um fortalecimento da primarização e, em seu limite, uma reprimarização que já atingiu importantes estados industriais, como Paraná e Rio Grande do Sul.

18 A esse conjunto de fatores, associamos a dinâmica própria do processo de acumulação capitalista que resulta da estratégia de concorrência das empresas quando se estabelecem em mercados fortemente oligopolizados. As empresas criam barreiras de entrada aos novos concorrentes, com o intuito de os manterem afastados da possibilidade de competição num mesmo mercado. (POSSAS, 1985). As barreiras resultam de definição de preços abaixo dos custos de produção, fusões ou aquisições, lobby com agentes governamentais e requisição de proteção de mercado através do poder político dos países onde estão instaladas suas matrizes. No atual estágio, torna-se cada vez mais difícil superar as barreiras de entrada em mercados já consolidados. Já não se trata apenas de definir participar das cadeias mas de quais o país tem condições mínimas de competir, o que já significaria um enorme esforço de mobilização de planejamento e fundos públicos. Para isso seria necessária uma forte atuação governamental apoiada em subsídios públicos, que pode ser crédito, garantia de financiamento de compra de produtos ou serviços e proteção até que se consolidassem no mercado interno e tivessem competência para disputar a concorrência internacional. Estas estratégias foram/são utilizadas de forma agressiva por países como China, Estados Unidos, Coreia do Sul e cada vez mais criticadas por organismos financeiros internacionais, especuladores ou mesmo por países que já atingiram um complexo estágio industrial, num processo que Friedrich List, economista alemão do século XIX, retomado por Chang (2004), chamou de "chutar a escada".

19 A economia brasileira, fragilizada desde o final dos anos noventa com políticas de desregulamentação, privatizações sem critérios compatíveis com um projeto de desenvolvimento nacional soberano, começou a apresentar indícios de desindustrialização e a consolidar, no início do século XXI, uma reprimarização da pauta exportadora. A desindustrialização tem sido discutida por autores como Rodrick (2016), Nassif (2008), Pereira Jr. (2012 e 2015), Sampaio (2015), Cano (2012), Gaulard (2015), Neuss (2018), entre outros. Nos limitaremos, nesta discussão, à reprimarização. 


\section{A reprimarização no território brasileiro}

20 Reprimarização da pauta exportadora é o fenômeno que ocorre quando há maior exportação de produtos primários em detrimento dos produtos industrializados, quando as exportações já haviam atingido comportamento inverso nos anos setenta. Quando um país deixa de exportar, relativamente, mais bens industriais do que primários, comumente representados por commodities agrícolas e minerais, temos a reprimarização. Para compreender o sentido da reprimarização da pauta exportadora, é necessário compreender o que representam as commodities. Classicamente, o termo refere-se a mercadorias de baixo valor agregado, mercadorias de baixa ou nenhuma transformação industrial. Caracterizam-se por serem razoavelmente homogêneas, com pouca diferenciação de qualidade. Dada a relativa padronização, sua competitividade, no mercado, está ancorada nos custos de produção (LAMOSO, 2011a) Portanto, quanto mais se consegue reduzir os custos, maior a margem de lucro visto que os preços são definidos no mercado internacional e não pelos produtores individuais. Também complementa suas características, o fato de serem produzidas e transportadas em grande escala e pesa sobre o custo do transporte um dos elementos de competitividade para a comercialização de commodities tanto agrícolas quanto minerais. A organização da produção e de sistemas de transporte em larga escala exercem considerável pressão sobre a produção do espaço geográfico, por isso a importância de compreendermos o que representam as commodities para a reprimarização das exportações brasileiras. Podemos citar como exemplo das principais exportadas pelo Brasil, o minério de ferro (commodity mineral), soja, milho, açúcar (commodities agrícolas).

21 A reprimarização pode ser generalizada para as exportações brasileiras como um todo, mas ela se particulariza de forma diferente nas unidades da federação. Há estados que sempre participaram do comércio internacional como vendedores de commodities, portanto a eles não se aplica o termo "reprimarização". Outros, que são nosso objeto especial de preocupação, já apresentavam um predomínio relativo nas exportações de manufaturados e semimanufaturados e o retorno a vendas de produtos básicos representa um retrocesso econômico e, por desdobramento, socioespacial. Por retrocesso socioespacial consideramos a ausência da verticalização da cadeia produtiva, maior pressão sobre o meio ambiente, precarização das relações de trabalho e fortalecimento de relações políticas conservadoras ou neoliberais.

A discussão sobre as implicações resultantes da dependência de commodities é complexa pois mesmo para a produção de básicos, para que sejam competitivos, há que se contar com incorporação de ciência e tecnologia, como no aperfeiçoamento de sementes, de herbicidas, inseticidas, adubos, sofisticação nos sistemas de transporte, cada vez mais automatizados e construídos para atender especificidades das mercadorias. Citamos, por exemplo, a construção de obras de engenharia para o transporte de minério de ferro do Quadriláterro Ferrífero de Minas Gerais até o Porto de Tubarão, via minerodutos encaixados na Serra do Mar que transportam por gravidade a popa de minério até os cargueiros transatlânticos (LAMOSO, 2011). Os grandes laboratórios mobilizam bilhões de dólares em pesquisas e a Embrapa brasileira também tem sua contribuição no aumento da produção em condições tropicais e subtropicais, com toda adversidade que solos, clima, disponibilidade hídrica, fauna e fatores antrópicos impõe ao sistema produtivo. 
Figura 4 - BRASIL - Evolução da participação relativa das exportações por fator agregado (2005-1015).

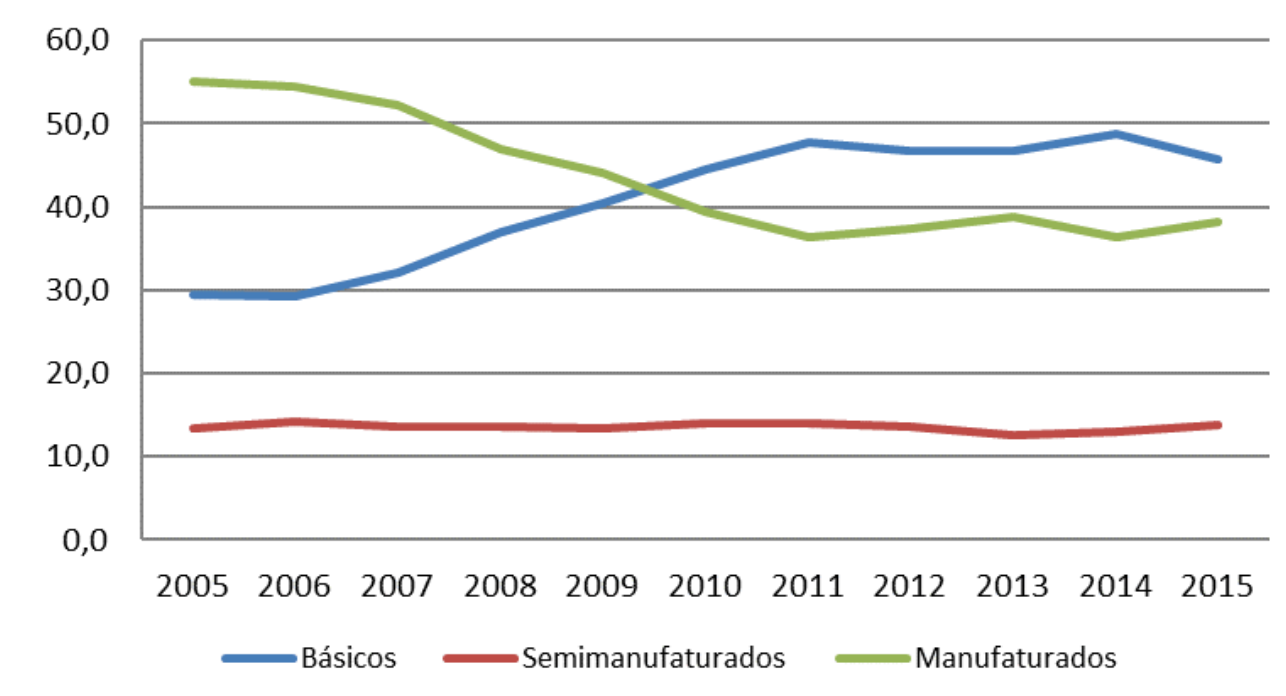

Fonte: MDIC, 2017. Org.: da Autora, 2019

Quando analisamos o retrato das exportações brasileiras por fator agregado no ano de 2018 (Ver Mapa 1), temos que a maior parte do território participa do comércio exterior com produtos primários.

Uma exportação que tenha maior participação desses produtos, consideramos como primária, em contraposição a uma exportação que tenha maior participação relativa de produtos industrializados ou semi-industrializados. Quando predominam os primários, chamaremos de primarização e quando as exportações já tiveram atingido um grau de sofisticação por fator agregado e depois retornar ao domínio dos primários, chamaremos de reprimarização.

nominal por fator agregado apresentou uma estabilidade dos semimanufaturados, queda dos manufaturados e crescimento dos produtos básicos, como podemos observar na Figura 1.

A queda dos manufaturados já está pronunciada no final de 2006, mesmo antes da crise de 2008, que impactou negativamente a venda de todos os tipos de produtos. Duas são as variáveis, interligadas, que explicam a variação positiva: o preço das commodities no mercado internacional (chamado "boom das commodities"), movimento cíclico da economia internacional; e um potente mercado consumidor, não apenas das exportações brasileiras como em geral, que é a China, motivada pela execução de seu plano de urbanização e implantação de infraestrutura. Muito embora haja associações entre o papel da China na desindustrialização brasileira, estudos de Jenkins (2015) relativizam seu papel.

7 A reprimarização da pauta exportadora pode ser datada no ano de 2009 (Ver Figura 4).

\section{Fonte: MDIC, 2017. Org: da Autora, 2019}

A composição da pauta de básicos ajuda a compreender como estão as estruturas produtivas bem como arriscarmos algumas proposições relacionadas aos fatos mais recentes ocorridos no território brasileiro, por isso apresentamos o comportamento das exportações dos principais produtos da pauta na Figura 5. 
nério de ferro, em ligeira alta desde 2006, tem uma queda após a crise de 2008 e um crescimento exponencial de mais de 40 bilhões de dólares até o ano de 2011, a partir do qual entra em declínio motivado pela queda de preços que resultaram das negociações entre o mercado chinês e australiano. Esse esforço de produção exigiu do aparato técnico instalado no território, trabalhar no limite da capacidade de produção, com política de redução de gastos.

Figura 5 - BRASIL - Evolução das exportações brasileiras de produtos básicos 2006 a 2018 (milhões US\$ FOB).

\section{Evolução das exportações brasileiras - 2006 a 2018}

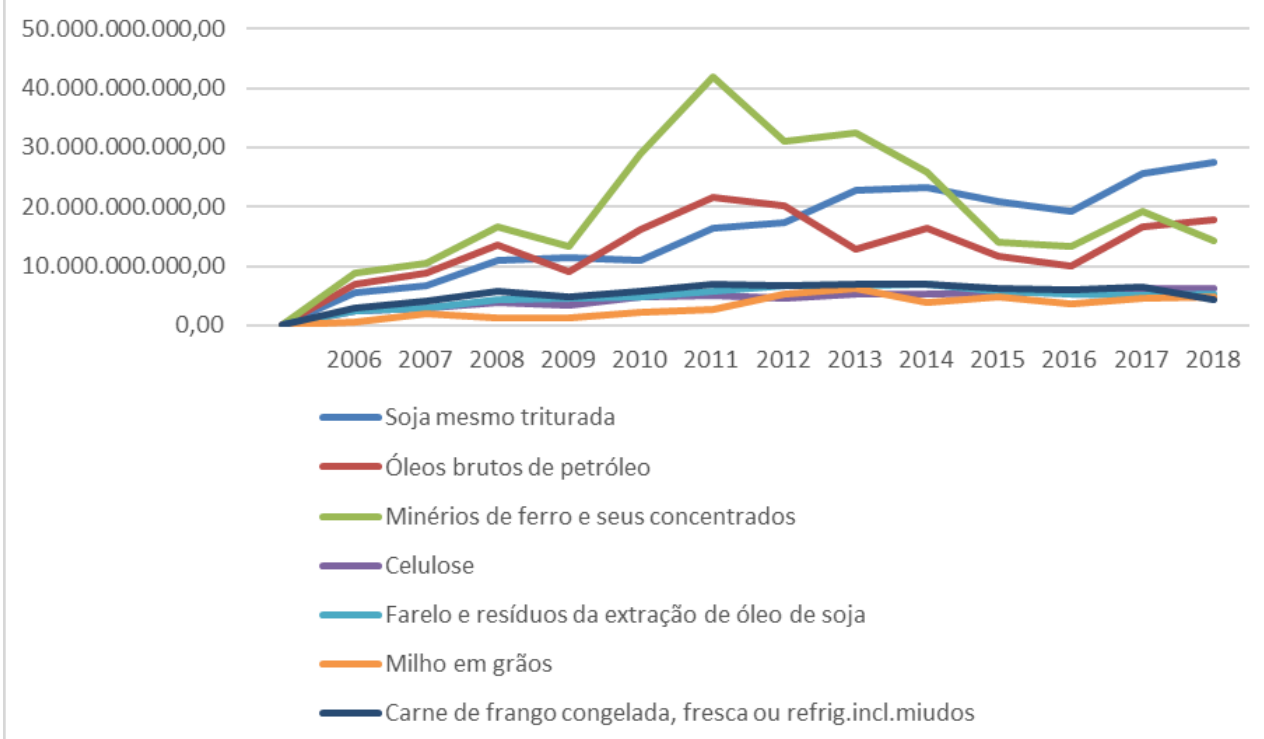

Fonte: MDIC, 2019 Org.: da Autora, 2019

Se considerarmos que a empresa Vale é a maior produtora de minério de ferro no Brasil (e no mundo), e a mesma é uma empresa que opera em bolsa de valores, distribuindo dividendos a acionistas e altamente financeirizada, temos um link para a relação entre o comportamento das exportações e o rompimento da barragem de Fundão, em MarianaMG, no ano de 2015 e da barragem da mina do córrego do Feijão, em Brumadinho-MG em 2019. A barragem de Fundão estava sob administração da empresa Samarco Minerações, uma joint venture entre a Vale e a Billiton Mineração. Minas Gerais, mantém-se mais como exportadora de básicos e menos como exportadora de aço ${ }^{2}$, um estado que já foi mais relevante em razão da expressão de seu parque siderúrgico. Produzir divisas com venda de minério e não de aço ou automóveis exige uma violenta pressão sobre a exploração de recursos naturais, para extração das rendas ricardianas.

31 As características da financeirização da empresa Vale foram detalhadamente abordadas em texto de Beluzzo e Sarti (2019) e podem, guardadas as especificidades, serem referência para a condição de outras empresas brasileiras. A financeirização, embora não seja uma estratégia nova, tem neste início de século se mostrado como elemento fundamental para explicar o comportamento da produção, comercialização, consumo e como exerce pressão sobre a base material instalada.

A soja permanece como um dos produtos mais exportados por onze estados. Em algumas situações, com transformação em óleo vegetal ou exportada, além da forma de 
grãos, como farelo e resíduos da extração do óleo para mercados que organizam o rebanho em confinamentos. Na melhor das hipóteses, como proteína animal nas exportações de aves e suínos.

A globalização impõe ao território suas demandas, mas é a Política a definidora de como esses vetores globais serão absorvidos e administrados. A Política implica em disputas de projetos e da correlação de forças entre frações de capital e, no caso brasileiro recente, a condição tem apontado para um retorno das práticas econômicas neoliberais, com redução, quando não desmonte da capacidade de intervenção do Estado, via privatizações ou enfraquecimento dos principais instrumentos financeiros, como o são os bancos públicos (Banco Nacional de Desenvolvimento Econômico e Social, Banco do Brasil, para citar dois). A globalização impõe, para a perseguição do desenvolvimento econômico, estados que consigam organizar a coalização formada por empresários industriais, classe trabalhadora, burocracia pública, em oposição às coalizões liberais dos capitalisitas rentistas, classe média rentista, financistas e interesses estrangeiros. Esta classificação foi tomada de Bresser-Pereira, Oreiro e Marconi (2016), bastante oportuna para a discussão sobre o papel da política no território.

34 A Figura 6 reúne a evolução do comportamento das exportações separadas por fator agregado dos 26 estados e o Distrito Federal. Com os dados se constata a heterogeneidade da distribuição espacial da reprimarização do território brasileiro. Os estados que apresentaram reprimarização foram: Acre e Amapá (embora ambos tenham um comportamento instável), Paraná e Rio Grande do Sul. Os dois últimos, na região sul, chamam a atenção por serem estados com indústrias maduras, são espaços onde se demonstra o crescimento do peso dos grãos, mais do que sua produção industrializada.

No Paraná, no ano de 2019, 21\% das exportações foram soja, 15\% para carnes de aves, miudezas comestíveis, frescas, refrigeradas ou congeladas. No Rio Grande do Sul, 22\% foi soja, o segundo produto foi tabaco descaulificado ou desnervado, com 8,8\% em 2019 (MDIC, 2020). 


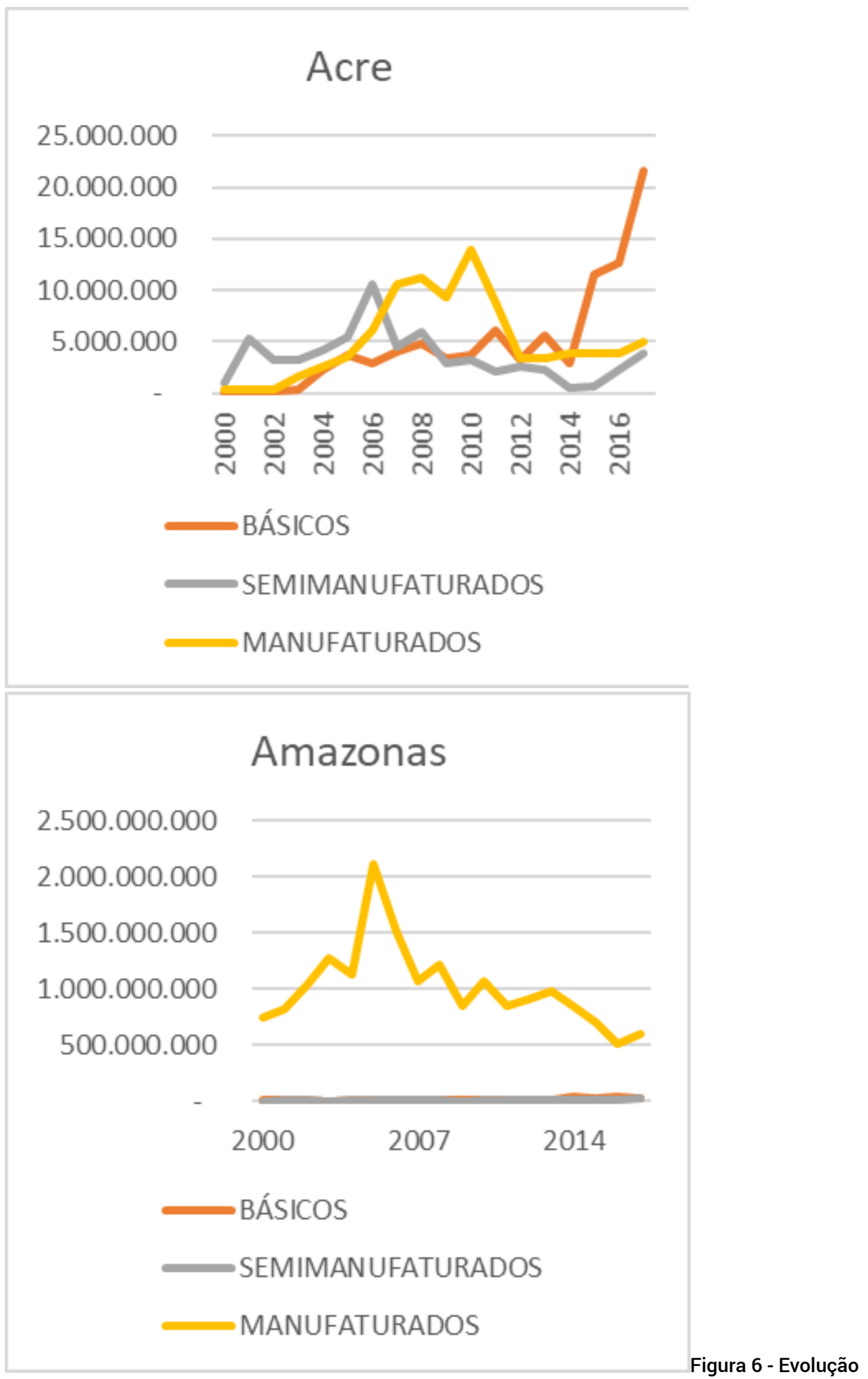

das exportações por fator agregado 2000 - 2017 em vários estados (em milhões US\$ FOB) 

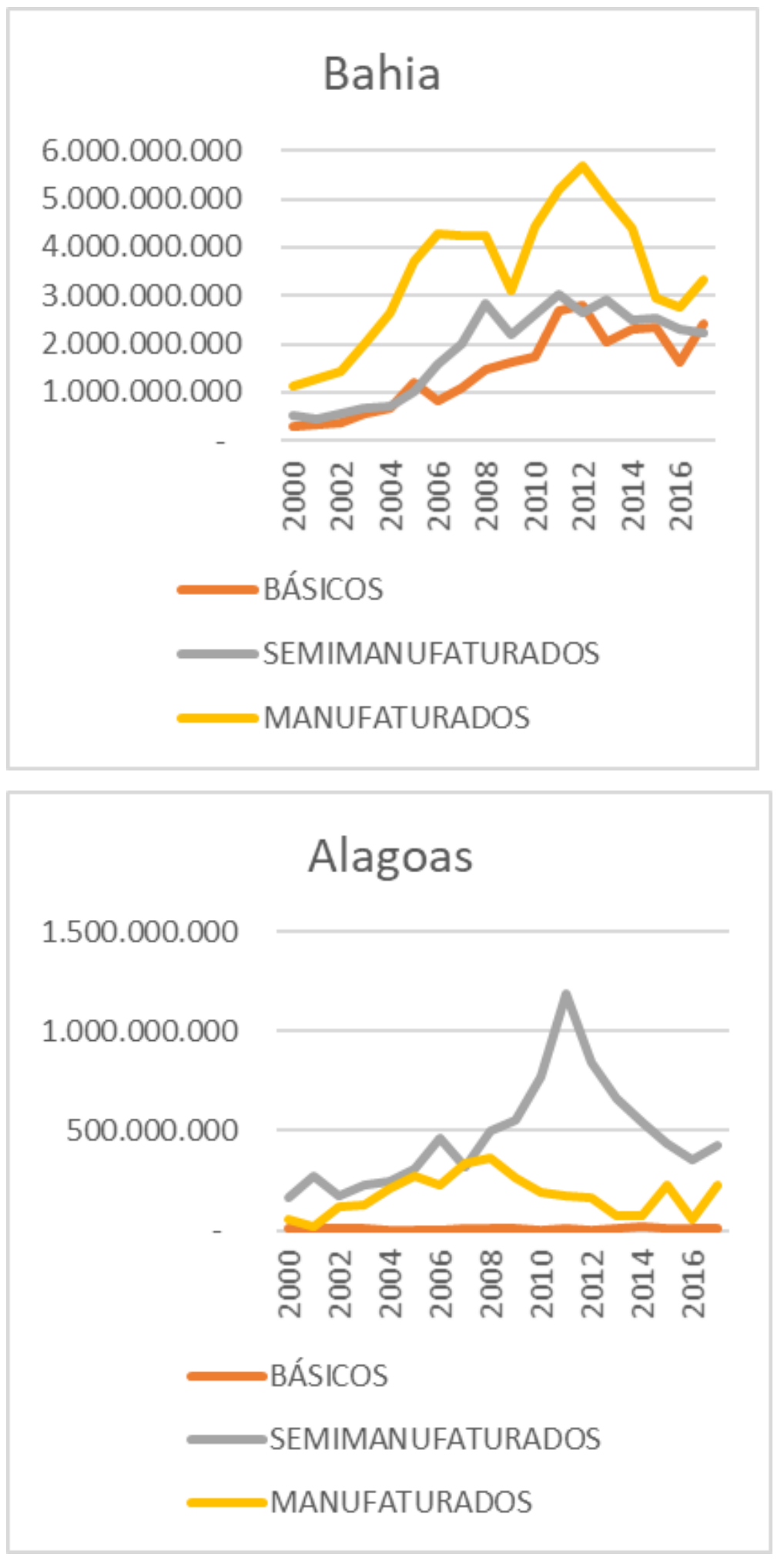

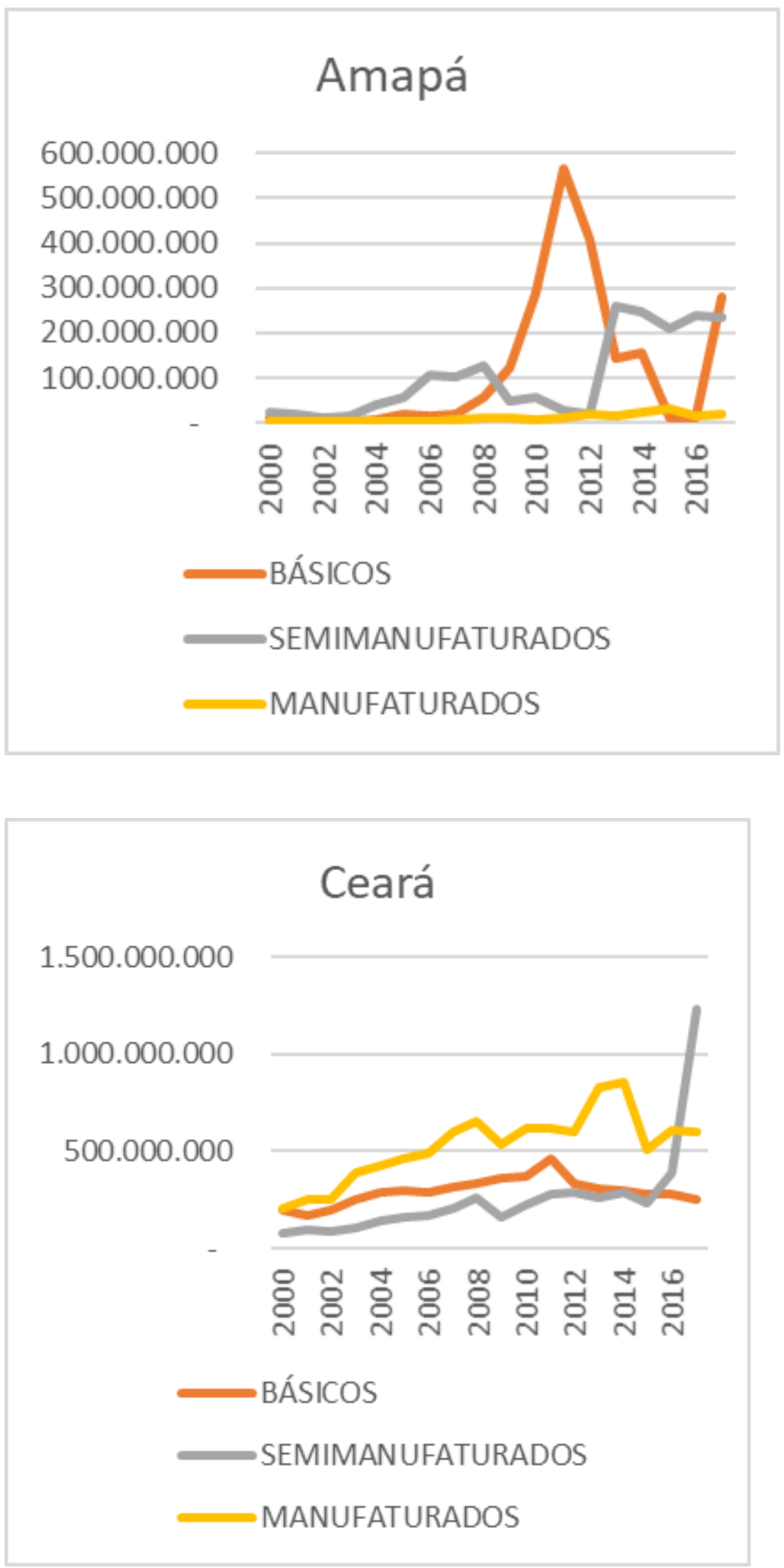


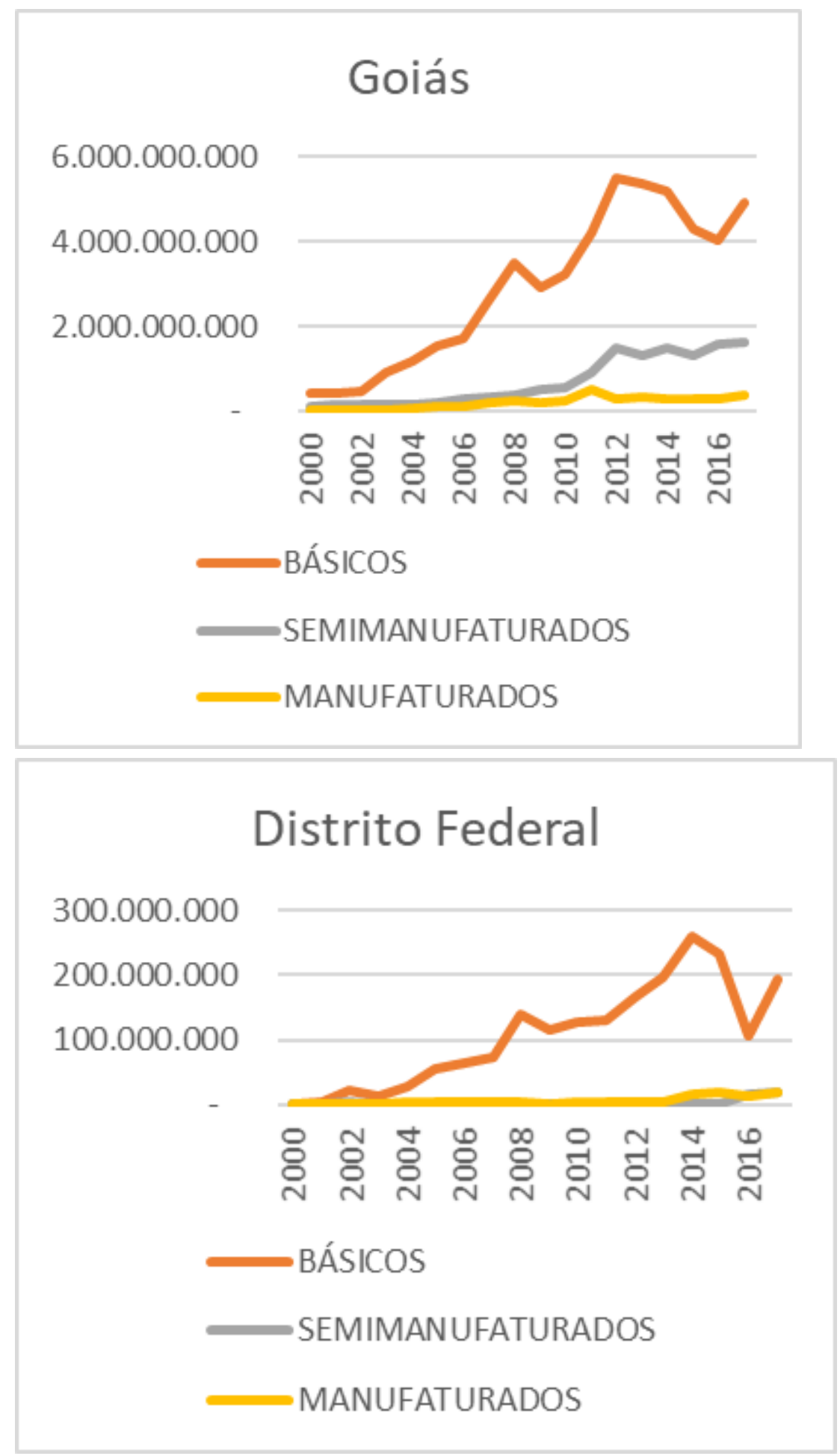



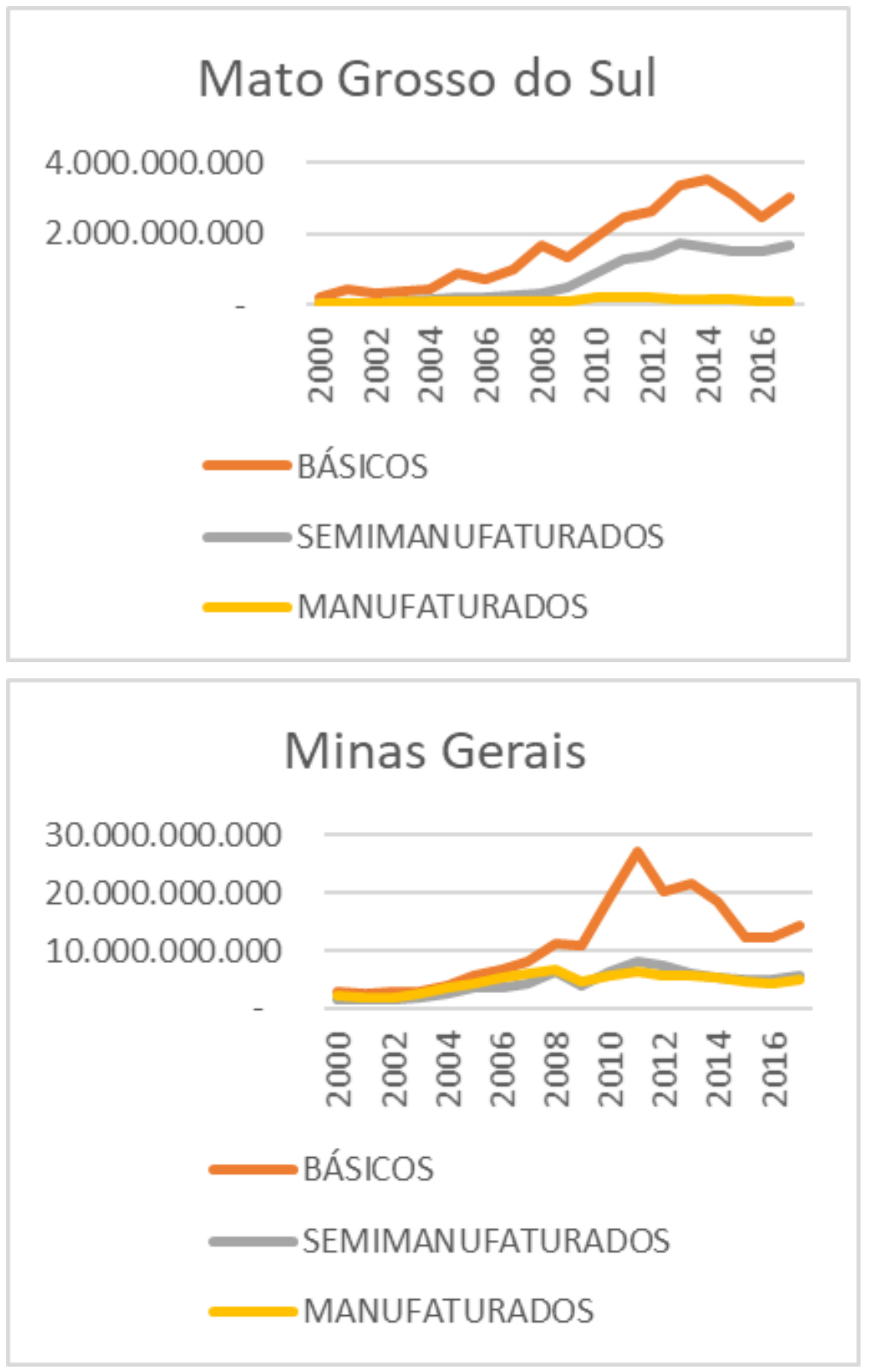


\section{Espírito Santo}
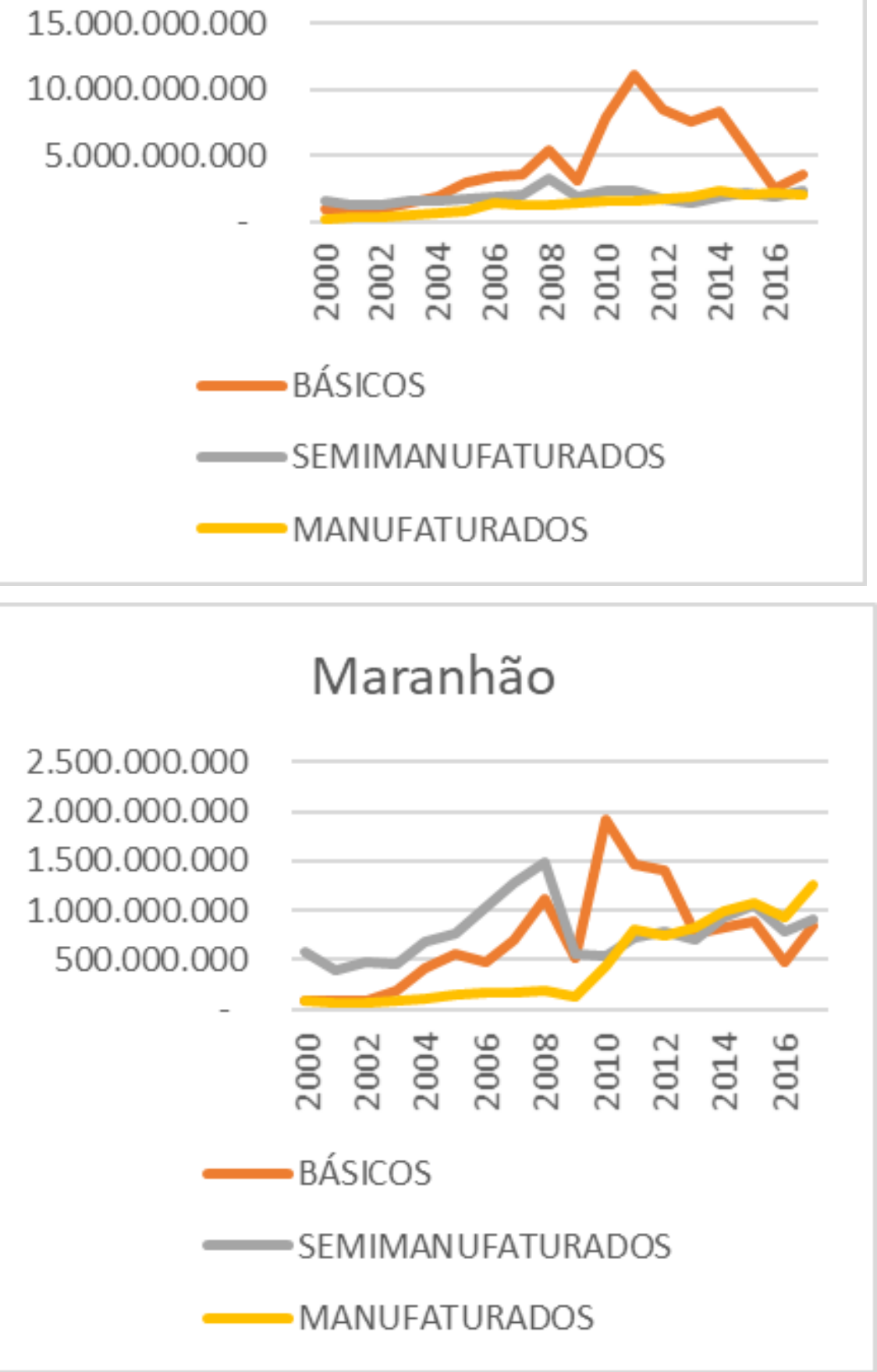


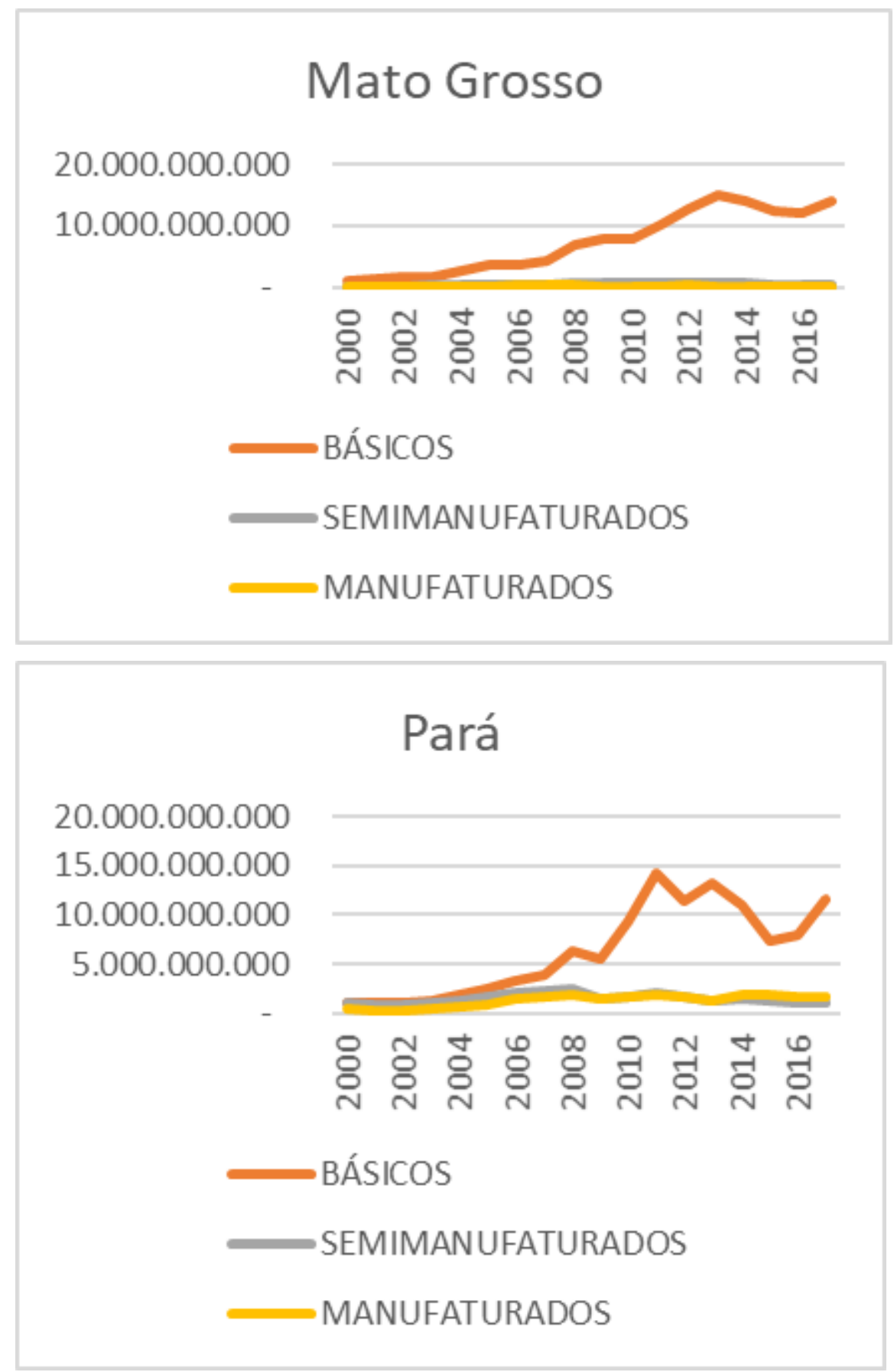




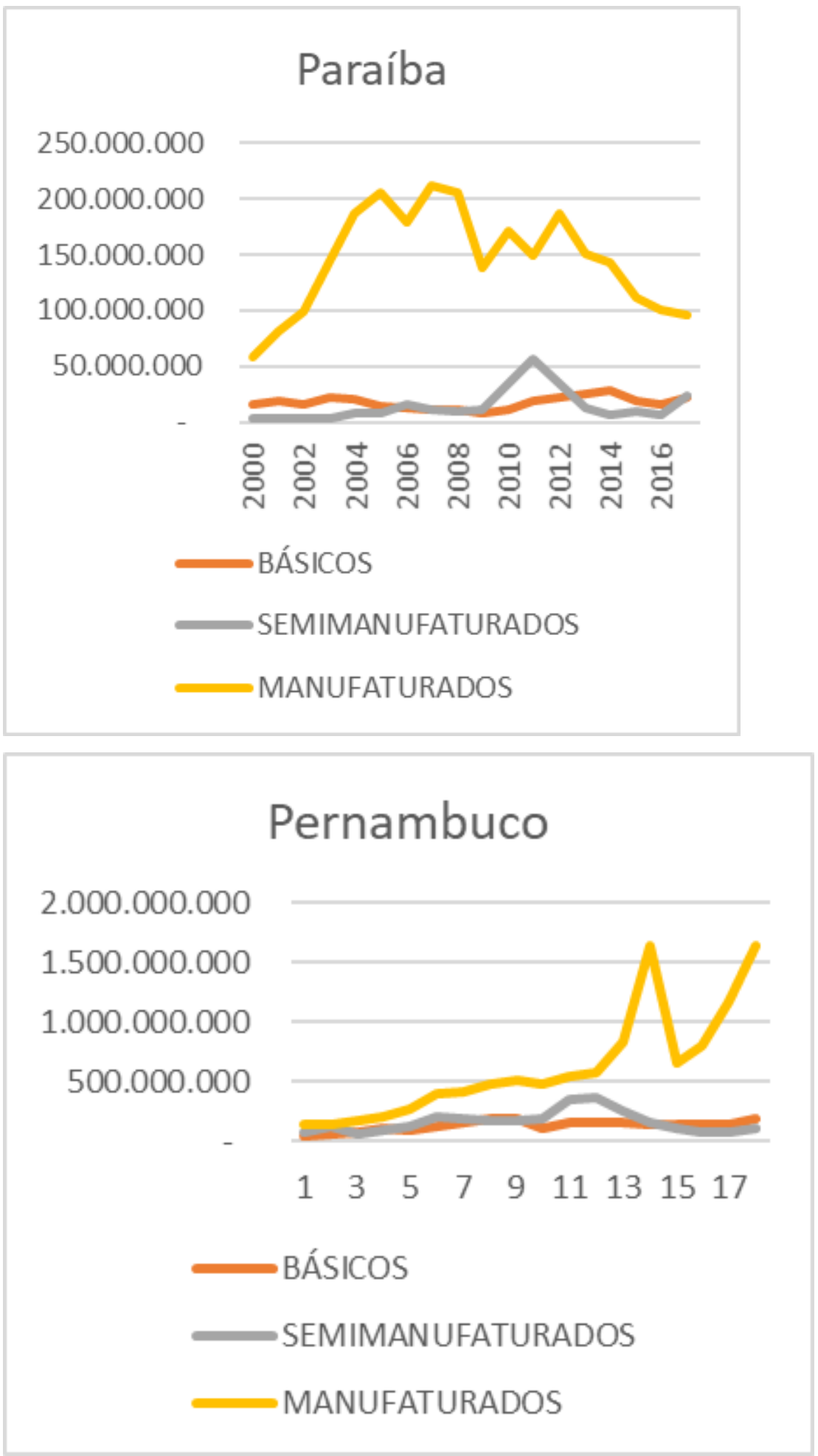




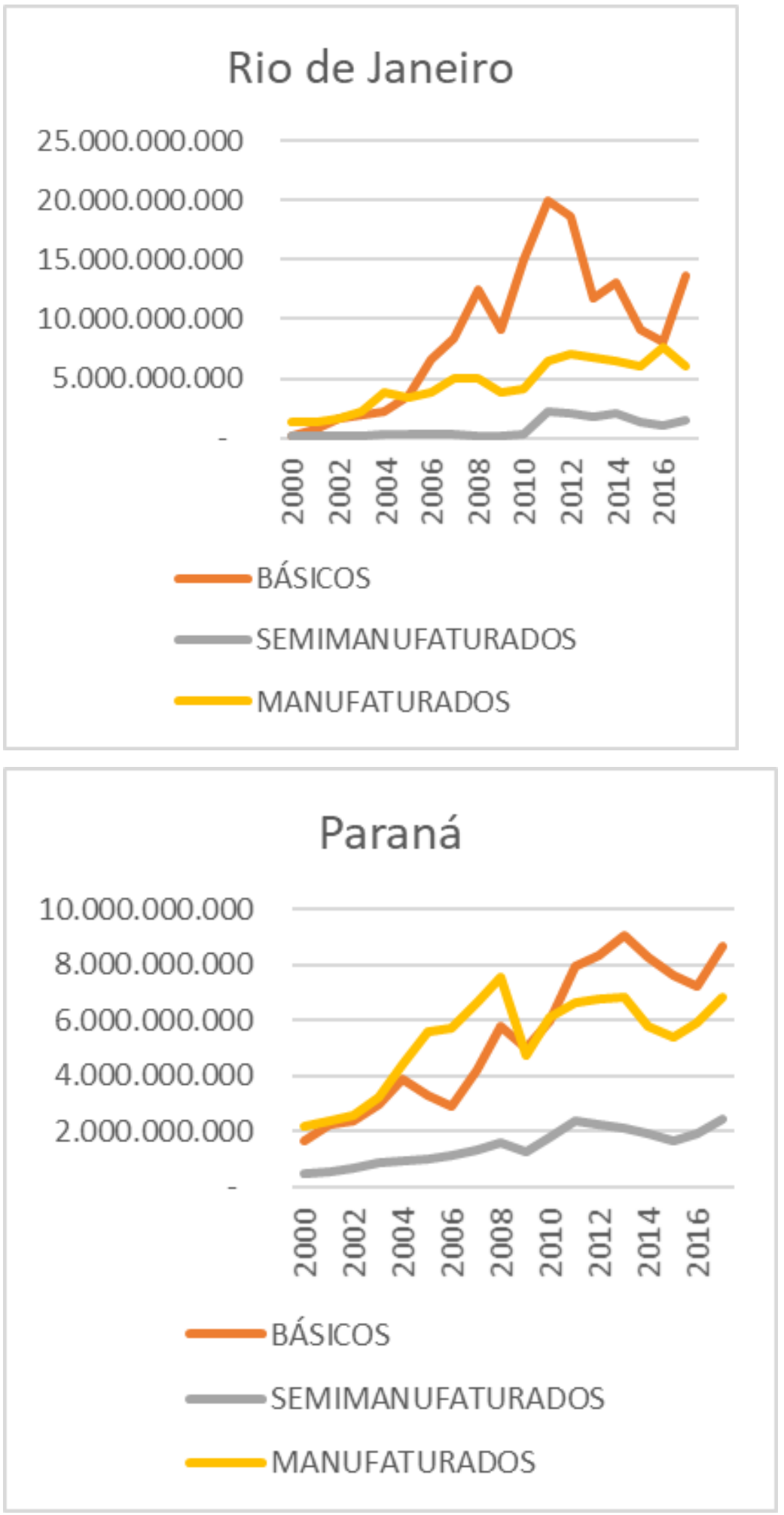



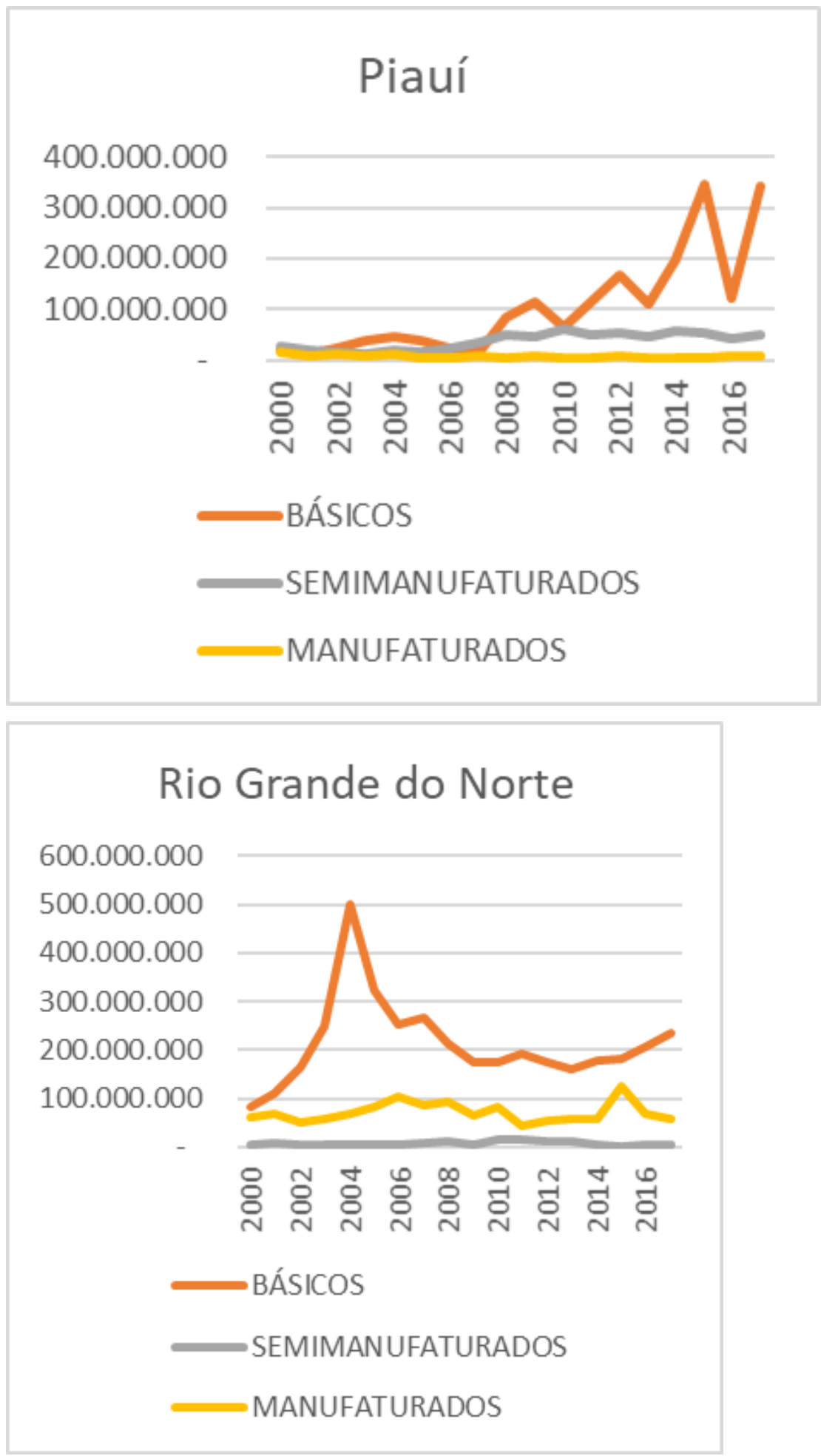


\section{Rio Grande do Sul}
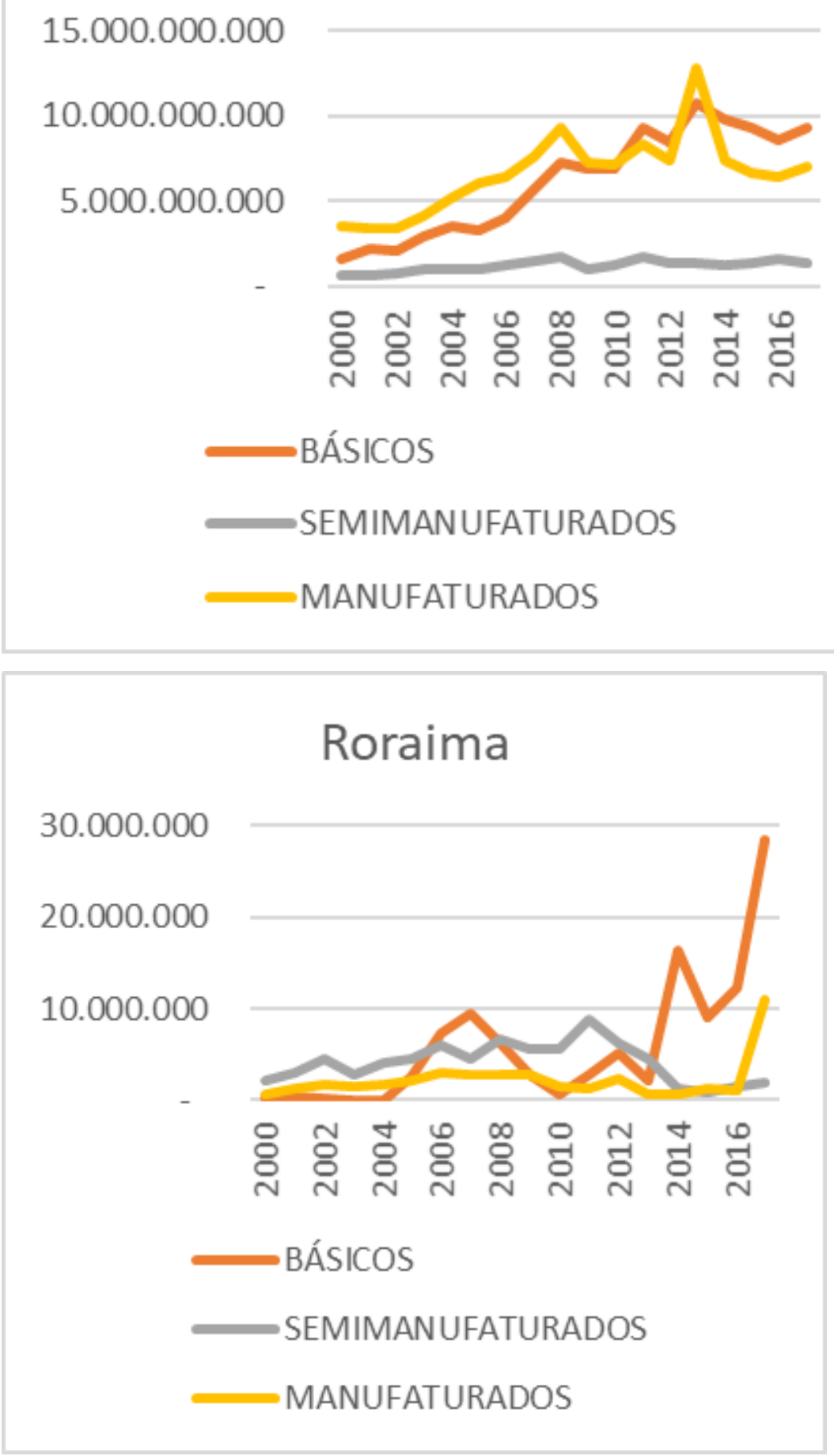


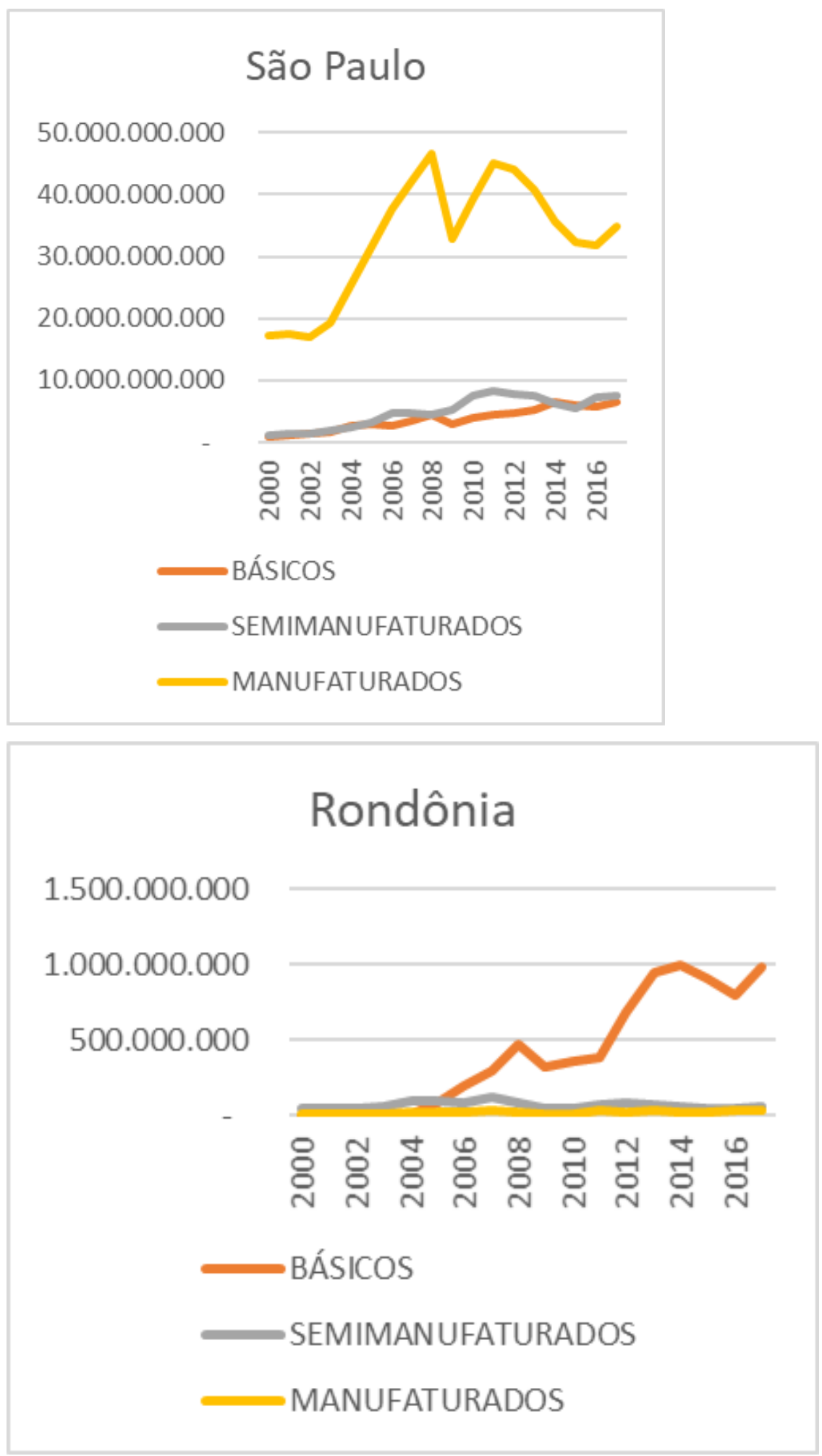



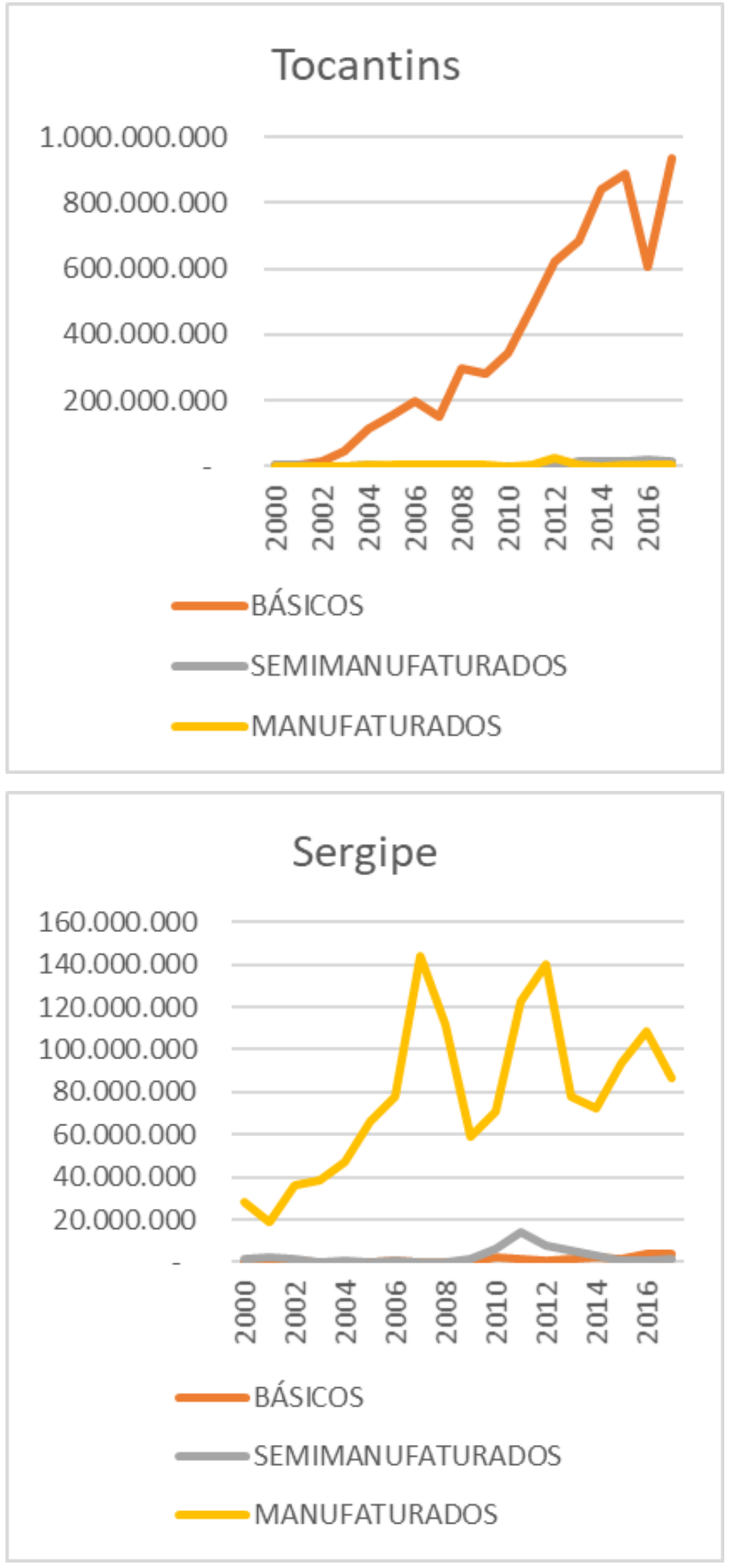


\section{Santa Catarina}

\subsection{0 .000 .000}

\subsection{0 .000 .000}

\subsection{0 .000 .000}

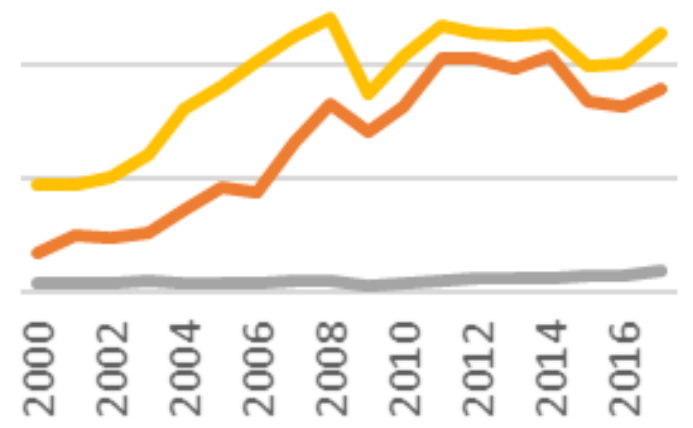

\section{BÁSICOS}

\section{SEMIMANUFATURADOS}

MANUFATURADOS

Fonte: MDIC, vários anos. Org.: da Autora, 2019

O movimento predominante foi de primarização, que significa a manutenção ou expansão das vendas de produtos básicos. Este movimento foi apresentado por dez estados: Goiás, Mato Grosso, Mato Grosso do Sul, Minas Gerais, Pará, Piauí, Rio de Janeiro, Roraima, Rondônia e Tocantins.

No território, a composição da pauta está distribuída pela predominante participação dos estados como fornecedores de produtos básicos.

Na Figura 6 temos os estados nos quais a indústria é desenvolvida, como São Paulo e Santa Catarina, no Centro-sul do País, bem como algo já esperado, que é a participação do estado do Amazonas, por causa da produção da Zona Franca de Manaus.

Ainda sobre a região norte, o Maranhão entra como exportador de industrializados por causa da produção de óxidos e hidróxidos de alumínio (43\%). A Paraíba, com participação de calçados (52\%), seguida por fios de algodão (6,2\%). O setor têxtil e alimentício, por tendência e característica, tem buscado áreas de menor custo de mão de obra, fator disponível na região Nordeste.

Em Pernambuco, o predomínio das exportações de óleo combustível (33\%), em Sergipe o suco de laranja congelado (54\%), ambos produtos de baixo valor agregado, embora classificados como industrializados. 
Figura 7 - BRASIL - Predominância das exportações por fator agregado - 2018

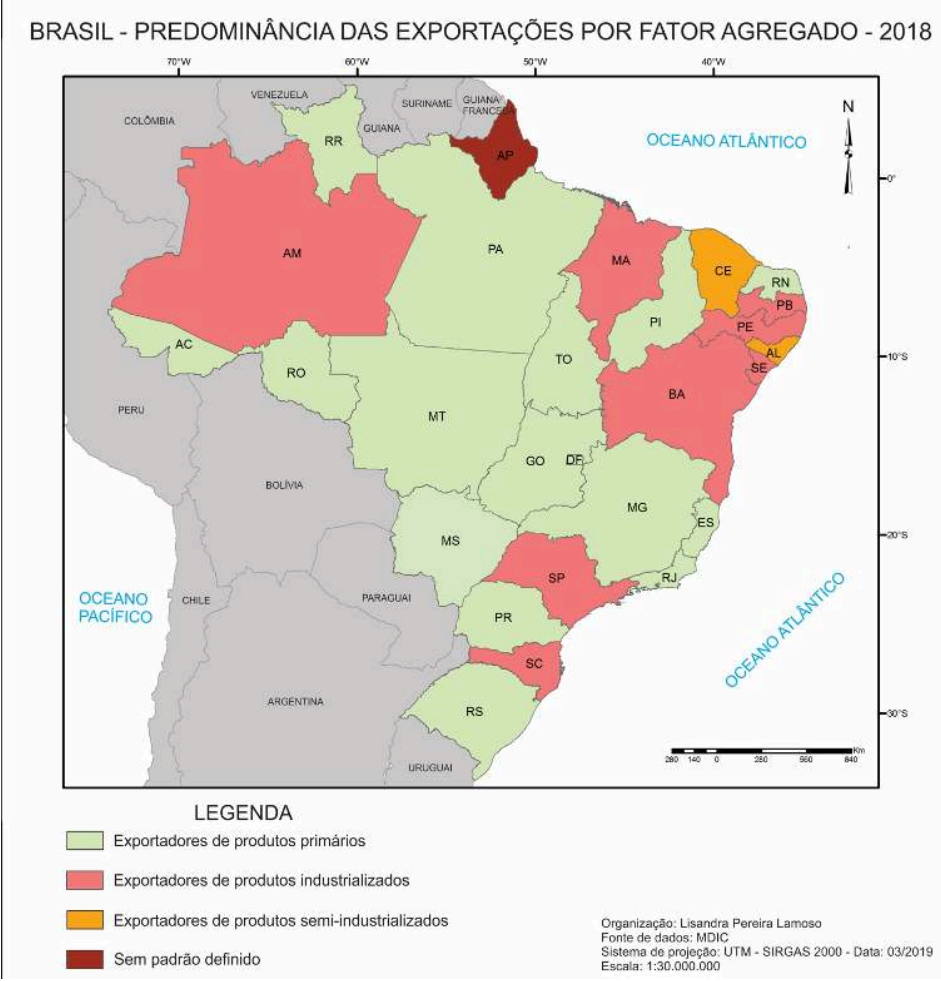

Se organizarmos um quadro síntese agrupando os estados nas regiões geográficas definidas pelo IBGE, temos a região Sul com dois importantes estados industriais exportando primários (Paraná e Rio Grande do Sul). Ambos com infraestrutura de transportes, ferrovias e sistemas portuários relevantes. No Sudeste, estão Rio de Janeiro (peso do petróleo), Minas Gerais (refém dos minérios) e Espírito Santo (que nem participa com os semimanufaturados do complexo celulose). O Centro-oeste é historicamente produtor de grãos, assim mantendo como exportadores seus quadro estados (Mato Grosso do Sul, Mato Grosso, Goiás, mais o Distrito Federal). Na região Norte, a exceção para o estado do Amazonas, em função da produção da Zona Franca de Manaus, ainda assim, perdendo valor agregado nas exportações, que poderiam ter as motocicletas e eletrônicos como primeiros produtos. O Nordeste, dos nove estados, tem cinco como exportadores de industrializados e semi-industrializados. É a região menos atingida na base de suas exportações, ainda que conte com produtos como suco de laranja e calçados. Mesmo assim, tanto Ceará como Alagoas, constam como exportadores de semimanufaturados, ou seja, é uma região que tem mantido uma inserção internacional pautada na superação da exportação de produtos primários. 
Quadro 1 - Síntese exportação por fator agregado por estados - 2018

\begin{tabular}{|c|c|c|c|c|}
\hline Sul & Sudeste & Centro-oeste & Norte & Nordeste \\
\hline $\begin{array}{l}\text { Santa } \\
\text { Catarina }\end{array}$ & São Paulo & $\begin{array}{l}\text { Mato Grosso do } \\
\text { Sul }\end{array}$ & Amazonas & Bahia \\
\hline Paraná & Rio de Janeiro & Mato Grosso & Acre & Sergipe \\
\hline \multirow{7}{*}{$\begin{array}{l}\text { Rio Grande } \\
\text { do Sul }\end{array}$} & Minas Gerais & Goiás & Rondônia & Maranhão \\
\hline & Espirito Santo & Distrito Federal & Roraima & Pernambuco \\
\hline & & & Pará & Paraiba \\
\hline & & & Tocantins & Rio Grande do Norte \\
\hline & & & Amapá & Piaui \\
\hline & & & & Ceará \\
\hline & & & & Alagoas \\
\hline
\end{tabular}

O Quadro 2 reúne os principais produtos industrializados, por valor exportado de estados selecionados nos quais predominam exportações de industrializados ou semiindustrializados. A intenção não é uma listagem exaustiva, por isso foi resumida nos primeiros produtos mais significativos. Mesmo nestes estados que não estão passando por reprimarização, praticamente são beneficiados pelo enquadramento das exportações, pois se trata de produtos com baixo valor agregado, baixa intensidade tecnológica (exceto São Paulo, cujo parque industrial diversificado que é tem uma variada gama de produtos, no ano de 2019, predominando químicos. Mesmo assim, chama a atenção que aeronaves e automóveis não estejam entre os primeiros). No Amazonas, a produção de motocicletas perde para produtos comestíveis e suas preparações. Em Santa Catarina, carnes de aves supera as exportações de seu parque elétrico. No Maranhão, predomina alumina, celulose e ferro-gusa. Na Paraíba, calçados e suco de frutas ou de vegetais, como em Sergipe. Em Pernambuco, óleo combustível. (Ver Quadro 2).

Quadro 2 - Principais produtos industrializados mais exportados por estados selecionados (2019)

\begin{tabular}{|c|c|}
\hline Estado & Produto \\
\hline Amazonas & $\begin{array}{l}\text { Outros produtos comestíveis e preparações }(27 \%) \text {, motocicletas, bicicletas } \\
\text { motorizadas ou não, e veículos para inválidos }(12 \%) \text {, ferro-gusa, spiegel, ferro } \\
\text { esponja, grânulos e pós de ferro ou aço e ferro-ligas }(8,5 \%) \text {, talheres }(6,2 \%) \text {. }\end{array}$ \\
\hline Bahia & $\begin{array}{l}\text { Óleo combustível de petróleo ou de minerais betuminosos (exceto óleos brutos); } \\
\text { celulose, ouro, demais produtos da indústria de transformação }(4,0 \%) \text {, cobre, } \\
\text { geradores elétricos giratórios e suas partes. }\end{array}$ \\
\hline Maranhão & Alumina (365), celulose (19\%), ferro-gusa $(4,0 \%)$, ouro. \\
\hline $\begin{array}{l}\text { Santa } \\
\text { Catarina }\end{array}$ & $\begin{array}{l}\text { Carnes de aves e suas miudezas (19\%), motores de pistão e suas partes }(4,85) \text {, } \\
\text { geradores elétricos giratórios e suas partes, madeira parcialmente trabalhada, } \\
\text { folheados contraplacados e suas partes. }\end{array}$ \\
\hline
\end{tabular}




\begin{tabular}{|l|l|}
\hline São Paulo & $\begin{array}{l}\text { Compostos organo-inorgânicos, compostos heterocíclicos, ácidos nucleicos e seus } \\
\text { sais (6,3\%), equipamentos de telecomunicações incluindo peças e acessórios (5,5\%), } \\
\text { válvulas e tubos termiônicos de cátodo frio ou foto-cátodo, diodos, transistores, } \\
\text { partes e acessórios de veículos automotivos, inseticidas, fungicidas, herbicidas para } \\
\text { crescimento de plantas, desinfetantes e semelhantes. }\end{array}$ \\
\hline Paraíba & $\begin{array}{l}\text { Calçados (54\%); fios têxteis (9,6\%), sucos de frutas ou de vegetais (5,15), açúcares e } \\
\text { melaços (4,3\%). }\end{array}$ \\
\hline Pernambuco & $\begin{array}{l}\text { Óleo combustível de petróleo (33\%); veículos automóveis de passageiros (12\%), } \\
\text { većúcares e melaços (8,9\%). }\end{array}$ \\
\hline Sergipe & $\begin{array}{l}\text { Suco de frutas ou de vegetais, calçados, outros produtos comestíveis e preparações. } \\
\text { óleos essenciais, matérias de perfume e sabor, açúcares e melaços, couro. }\end{array}$ \\
\hline
\end{tabular}

FONTE: MDIC, 2020 ORg.: DA AUTORA, 2019.

\section{Considerações Finais}

A Globalização apresenta seus elementos de força, que são: Peso das corporações nas decisões de política econômica; Financeirização cada vez maior dos grupos produtivos; Grau de agregação de valor das mercadorias inseridas no mercado internacional via exportações; Capacidade de atração de Investimentos Estrangeiros Diretos para aumento da capacidade instalada; Outsourcing - terceirizações off shore; Qualidade da participação nas Cadeias Globais de Valor (Global Value Chains); Competição em custos, mão de obra, escala e taxa de câmbio e Estratégias de competição baseadas em "barreiras à entrada" em mercados oligopolizados. Esses elementos, direta ou indiretamente, são definidores do processo de reprimarização. Após uma breve apresentação, o texto se dedicou a analisar qual é o comportamento das exportações por unidades da federação, apresentando 27 gráficos com exportações por fator agregado.

Os gráficos e o Mapa das exportações por fator agregado no ano de 2018 demonstram onde o processo ocorre. Os estados do Paraná e Rio Grande do Sul passaram por reprimarização da pauta exportadora. 0 Estado do Ceará aumentou as exportações de semimanufaturados, embora a trajetória dos manufaturados fosse superior até o ano de 2015. A maioria dos estados, Espírito Santo, Goiás, Mato Grosso do Sul, Mato Grosso, Minas Gerais, Pará, Piauí, Rio Grande do Norte, Rondônia e Tocantins, ampliaram a participação dos básicos nas exportações.

A relação de produtos exportados pelos estados que não apresentaram reprimarização é de baixa intensidade tecnológica, o que indica um alerta caso persistam orientações de política econômica de cunho neoliberais, despreocupadas com o processo de desenvolvimento econômico nacional.

47 A intensidade na exploração dos recursos naturais permite aos países realizarem uma acumulação primitiva mas se as rendas vão para fora do país, drenadas pelos compromissos financeiros especulativos e a isso se associar a redução do estado como planejador e o enfraquecimento de bancos públicos como instrumentos de apoio ao 
desenvolvimento industrial, a conjuntura apresenta um quadro preocupante, sem tendências de melhora apontadas para o curto prazo.

\section{BIBLIOGRAFIA}

ARROYO, Mónica. Flujos mercantiles y division territorial del trabajo en Brasil. Revista Geográfica Venezolana. [en linea]. V.55. n.1. enero-junio. p.155-172, 2014.

BALDWIN, Richard. Trade and industrialization after globalisation's 2nd unbundling: how building and joining a supply chain are different and why it matters. Cambridge, MA: National Bureau of Economic Research, Working Paper 17716, dez. 2011. Disponível em https:// www.nber.org/ papers/w17716. Acesso em: 12 de janeiro de 2019.

BELUZZO, Luis Gonzaga; SARTI, Fernando. Vale, uma empresa financeirizada. Le Monde Diplomatique, 10fev2019. Disponível em <, 2012https://diplomatique.org.br/valeumaempresafinanceirizada/? fbclid=IwAR2iMGM30WOrzhKQzvVEeaWILVa0TZYsNdx4QXR__Tyu_cGGWWEpENYncpo.> Acesso em: 28 de janeiro de 2019.

CANO, Wilson. A desindustrialização no Brasil. Economia e Sociedade. V. 21, p.831-851, 2012

BRESSER-PEREIRA, Luis Carlos; OREIRO, José.; MARCONI, Nelson. Macroeconomia desenvolvimentista: teoria e política econômica do novo desenvolvimentismo. 1ed. Rio de Janeiro : Campus, 2016.

CHANG, Ha Joon. Chutando a escada: a estratégia do desenvolvimento em perspectiva histórica. São Paulo : Editora da Unesp, 2004.

FERREIRA, Jonathan Dias; SCHNEIDER, Mirian Beatriz. As cadeias globais de valor e a inserção da indústria brasileira. Revista Tecnologia e Sociedade. Curitiba, v.11, n.21, 2015. Disponível em $<$ https://periodicos.utfpr.edu.br/rts/article/download/3012/2425>. Acesso em: 14 de fevereiro de 2019.

FUNDO MONETÁRIO INTERNACIONAL. Maiores economias do mundo: PIB a preço corrente em bilhões de dólares. Disponível em <http://www.funag.gov.br/ipri/index.php/o-ipri/47estatisticas/94-as-15-maiores-economias-do-mundo-em-pib-e-pib-ppp>. Acesso em: 9 de abril de 2019.

GAULARD, Mylène. The brazilian deindustrialization: financialization is not guilty. Revista de Economia Política. v.35, n.2, 2015.

HIRATUKA, Celso.; SARTI, Fernando. Transformações na estrutura produtiva global, desindustrialização e desenvolvimento industrial no Brasil. Revista de Economia Política, v. 37, n. 1 (146), pp. 189-207, janeiro-março/2017. Disponível em <http://www.rep.org.br/PDF/146-10.PDF>. Acesso em: 8 de janeiro de 2019.

HUMPHREY, John.; SCHIMITZ, Hubert. How does insertion in global value chains affect upgrading in industrial clusters? Regional Studies. V.36, n.9, 2002. p. 1017-1027. 
KALDOR, Nicholas. Strategic Factors in economic Development, New York State School of Industrial and Labor Relations, Cornel University: Ithaca NY, 1967, 83p.

JENKINS, Rhys. Is chinese competition causing deindustrialization in Brazil? Latin American Perspectives. V.32, n.6. nov. p.42-63, 2015.

LAMOSO, Lisandra Pereira. Commodities. In: SILVEIRA, Márcio Rogério. Circulação, transportes e logística: diferentes perspectivas. São Paulo : Outras Expressões, 2011a.

. Fluxos e redes técnicas no comércio de minério no território brasileiro. In:

SILVEIRA, Márcio Rogério. Circulação, transportes e logística: diferentes perspectivas. São Paulo : Outras Expressões, 2011b. p.355-376.

MINISTÉRIO DO DESENVOLVIMENTO, INDÚSTRIA E COMÉRCIO. Estatísticas de comércio exterior. Vários anos. Disponível em <http://www.mdic.gov.br/index.php/comercio-exterior/estatisticasde-comercio-exterior> Acesso em 23 de março de 2019.

NASSIF, André. Há evidências de uma desindustrialização no Brasil? Revista de Economia Política. v. 28 n.1, 2008.

NEUSS, Leif van. Globalization and deindustrialization in advanced countries. Structural change and economic dynamics. v.45, 2018, p. 49-63. Disponível em https://ideas.repec.org/a/eee/streco/ v45y2018icp49-63.html>. Acesso em: 4 de janeiro de 2019.

PEREIRA JUNIOR, Edilson. Análise de abordagens concorrentes sobre industrialização, território e políticas econômicas. Revista GeoUECE, v. 1, pp. 15-28, 2012. Disponível em http://seer.uece.br/? journal=geouece\&page $=$ article\&op=view\&path\%5B\%5D=417\&path\%5B\%5D=513. Acesso em: $8 \mathrm{de}$ março de 2019

. Dinâmicas industriais e urbanização no Nordeste do Brasil. Mercator. v. 14, p. 63-81, 2015. Disponível em http://www.scielo.br/pdf/mercator/v14nspe/1984-2201-mercator-14-04spe-0063.pdf. Acesso em: 18 de fevereiro de 2019

POSSAS, Mário Luis. Estruturas de mercado em oligopólio. São Paulo: Hucitec, 1985.

RANGEL, Ignácio. Ciclo, tecnologia e crescimento. In: BENJAMIM, Cesar (org). Obras reunidas. v.2, São Paulo: Contraponto. p. 255-408, 2005.

RODRIK, Dani. Premature deindustrialization. Journal of Economic Growth. n.21. p.1-33, 2016

SAMPAIO, Daniel Pereira. Desindustrialização e estruturas produtivas regionais no Brasil. Tese (Doutorado em Desenvolvimento Econômico). Instituto de Economia. Unicamp. Campinas, 2015. 236p.

SANTOS, Milton. A natureza do espaço. São Paulo : Hucitec, 1996.

. Por uma outra globalização: do pensamento único à consciência universal. São Paulo : Record, 2000.

SARTI, Fernando.; HIRATUKA, Celso. Desempenho recente da indústria brasileira no contexto de mudanças estruturais domésticas e globais. Texto para Discussão. IE/Unicamp, Campinas, n. 290, abril, 2017.

SCHUMPETER, Joseph. Teoria do desenvolvimento econômico. São Paulo : Abril Cultural, [1957], 1982.

WORD TRADE ORGANIZATION. Brazil. 2017. Disponível em

< https://www.wto.org/english/res_e/statis_e/daily_update_e/trade_profiles/BR_e.pdf>.Acesso em 12 de março de 2019. 


\section{NOTAS}

1. Agradecimentos: Ao Conselho de Desenvolvimento Científico e Tecnológico (CNPq) pela Bolsa de Produtividade em Pesquisa II, com período de vigência de março de 2019 a março de 2022.

2. Em 2019, as exportações de minério de ferro e seus concentrados representaram $29 \%$ do total em milhões de dólares. Ferro-gusa, spiegel, ferro-esponja, grânulos e pó de ferro ou aço e ferro ligas, $11 \%$ do total.

\section{RESUMOS}

Reprimarização representa maior exportação relativa de produtos básicos em relação aos manufaturados e semimanufaturados, após o país exportador já ter alcançado situação inversa em anos anteriores. A economia globalizada está caracterizada pela presença de oligopólios, empresas financeirizadas, disputas por mercados competitivos com barreiras de entrada, tendência ao esgotamento do "boom de commodities", implementação de políticas protecionistas por mercados tradicionais e protagonismo da demanda chinesa. Neste contexto, a ausência de um projeto de desenvolvimento econômico nacional expõe o território brasileiro à desindustrialização e a uma reprimarização, com perda de complexidade econômica. Este texto apresenta a reprimarização no território brasileiro, a partir de gráficos das exportações estaduais por fator agregado no período de 2000 a 2016. Constata-se um processo de reprimarização heterogênea no território nacional, contudo, ela é mais grave nos estados do Paraná e Rio Grande do Sul. A maioria dos estados fortalece a primarização e os que se mantêm na exportação de produtos industrializados, o fazem com base em mercadorias de baixa intensidade tecnológica.

Reprimarization constitutes a greater relative export of basic products in relation to manufactured and semi-manufactured products, after a given exporting country has already reached the opposite situation in previous years. The globalized economy is characterized by the presence of oligopolies, financialized enterprises, disputes over competitive markets with barriers to entry, a tendency to the exhaustion of "commodities boom", implementation of protectionist policies by traditional markets, as well as the leading role of Chinese demand. In this context, the absence of a national economic development project makes the Brazilian territory vulnerable to deindustrialization and reprimarization, with a consequent loss in economic complexity. This paper shows the reprimandization in the Brazilian territory, based on state exports graphs by aggregate factor, from 2000 to 2016. It also shows that there is a process of heterogeneous reprimarization in the national territory, however, it is more serious in the states of Paraná and Rio Grande do Sul. Most states strengthen primarization and those that continue to export industrialized products do so on the basis of low-tech goods.

La reprimarización representa una mayor exportación relativa de productos básicos en relación con productos manufacturados y semimanufacturados, después de que el país exportador ya haya alcanzado la situación opuesta en años anteriores. La economía globalizada se caracteriza por la presencia de oligopolios, compañías financierizadas, disputas sobre mercados competitivos con barreras de entrada, una tendencia a agotar el "boom de los productos básicos", la implementación de políticas proteccionistas por parte de los mercados tradicionales y el papel principal de la demanda china. En este contexto, la ausencia de un proyecto nacional de desarrollo económico expone al territorio brasileño a la desindustrialización y la 
reprimarización, con una pérdida de complejidad económica. Este texto presenta la reprimarización en el territorio brasileño, basada en gráficos de exportaciones estatales por factor agregado en el período 2000 a 2016. Hay un proceso de reprimarización en el territorio nacional, sin embargo, es más grave en los estados de Paraná y Rio Grande del Sur. La mayoría de los estados fortalecen la primarización y aquellos que continúan exportando productos industrializados lo hacen en base a bienes de baja intensidad tecnológica.

A l'heure actuelle, l'économie mondialisée est caractérisée par des aspects tels que la présence d'oligopoles, les disputes autour des marchés compétitifs, les politiques protectionnistes, la financiarisation des entreprises, la tendance à l'épuisement du boom des commodities et le protagonisme de la demande chinoise. Dans ce contexte, l'absence d'un projet de développement national expose le Brésil tant à la désindustrialisation quant à la reprimarisation du territoire. A partir des graphiques d'exportations du facteur agrégé extraits des états de la fédération pendant la période 2000-2016, on constate la reprimarisation dans la plupart d'eux, surtout au Paraná et au Rio Grande do Sul. Même les états capables d'exporter des produits industrialisés le faisaient à partir de marchandises à faible technologie.

\section{ÍNDICE}

Mots-clés: mondialisation, développement économique, réprimarisation, commerce extérieur, Brésil.

Palabras claves: Globalización. Desarrollo económico. Reprimarización. Comercio Exterior.

Keywords: Globalization. Economic development. Reprimarization. Foreign trade.

Palavras-chave: globalização, desenvolvimento econômico, reprimarização, comércio exterior.

\section{AUTOR}

\section{LISANDRA PEREIRA LAMOSO}

Doutora em Geografia Humana pela Universidade de São Paulo. Docente do Programa de Pósgraduação em Geografia da Universidade Federal da Grande Dourados (UFGD). Membro do Grupo de Pesquisa Desenvolvimento Regional e Infraestrutura (GEDRI). E-mail:

lisandralamoso@ufgd.edu.br. 